\title{
Repairing oxidized proteins in the bacterial envelope using respiratory chain electrons
}

Alexandra Gennaris ${ }^{1,2,3 *}$, Benjamin Ezraty ${ }^{4}$, Camille Henry ${ }^{4}$, Rym Agrebi $^{1,2,3}$, Alexandra Vergnes ${ }^{4}$, Emmanuel Oheix ${ }^{5}$, Julia Bos ${ }^{4} \uparrow$, Pauline Leverrier ${ }^{1,2,3}$, Leon Espinosa ${ }^{4}$, Joanna Szewczyk ${ }^{1,2,3}$, Didier Vertommen ${ }^{2}$, Olga Iranzo $^{5}$, Jean-François Collet ${ }^{1,2,3}$ \& Frédéric Barras ${ }^{4}$

The reactive species of oxygen and chlorine damage cellular components, potentially leading to cell death. In proteins, the sulfur-containing amino acid methionine is converted to methionine sulfoxide, which can cause a loss of biological activity. To rescue proteins with methionine sulfoxide residues, living cells express methionine sulfoxide reductases (Msrs) in most subcellular compartments, including the cytosol, mitochondria and chloroplasts $^{1-3}$. Here we report the identification of an enzymatic system, MsrPQ, repairing proteins containing methionine sulfoxide in the bacterial cell envelope, a compartment particularly exposed to the reactive species of oxygen and chlorine generated by the host defence mechanisms. MsrP, a molybdo-enzyme, and MsrQ, a haem-binding membrane protein, are widely conserved throughout Gram-negative bacteria, including major human pathogens. MsrPQ synthesis is induced by hypochlorous acid, a powerful antimicrobial released by neutrophils. Consistently, MsrPQ is essential for the maintenance of envelope integrity under bleach stress, rescuing a wide series of structurally unrelated periplasmic proteins from methionine oxidation, including the primary periplasmic chaperone SurA. For this activity, MsrPQ uses electrons from the respiratory chain, which represents a novel mechanism to import reducing equivalents into the bacterial cell envelope. A remarkable feature of MsrPQ is its capacity to reduce both rectus $(R-)$ and sinister $(S$-) diastereoisomers of methionine sulfoxide, making this oxidoreductase complex functionally different from previously identified Msrs. The discovery that a large class of bacteria contain a single, non-stereospecific enzymatic complex fully protecting methionine residues from oxidation should prompt a search for similar systems in eukaryotic subcellular oxidizing compartments, including the endoplasmic reticulum.

The fact that no Msr had been identified in the cell envelope of important human pathogens, including Escherichia coli and Pseudomonas aeruginosa, was surprising as this compartment is particularly exposed to the oxidizing compounds present in the environment. We postulated that such a methionine sulfoxide (Met-O) reducing system had remained unidentified, and applied a genetic approach to uncover it, using E. coli as a model. We first constructed an E. coli Met auxotroph mutant lacking all cytoplasmic Msrs and found this strain (JB590) to be unable to use Met-O as the only Met source (Fig. 1a). We then searched for suppressor mutations conferring Met-O reducing capacity to JB590, which led to the isolation of strain BE100 (Fig. 1a). Genetic analysis of the suppressor revealed the presence of an insertion sequence element (IS2) within yed $V$, a gene coding for the histidine kinase of the uncharacterized YedV/YedW two-component system $^{4}$. In close vicinity were two genes, yed $Y$ and yed $Z$, encoding, respectively, a periplasmic molybdopterin-containing oxidoreductase and its putative membrane redox partner ${ }^{5,6}$. YedY had been shown to reduce a variety of substrates in vitro, including trimethylamine $\mathrm{N}$-oxide, and dimethyl, methionine and tetramethylene sulfoxides ${ }^{5}$. However, its physiological function had remained elusive, although a recent study in Azospira suillum suggested the homologous protein to

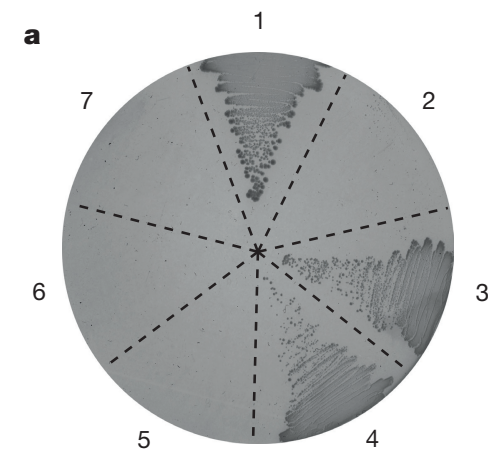

b yedYyedZ mRNA level
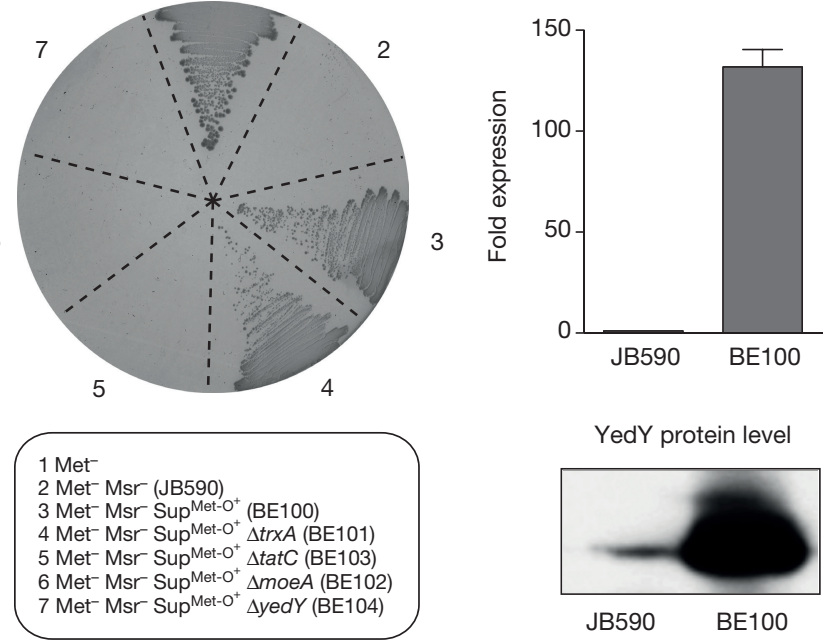

YedY protein leve

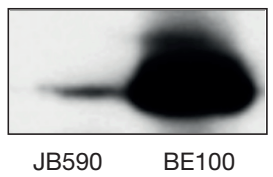

C

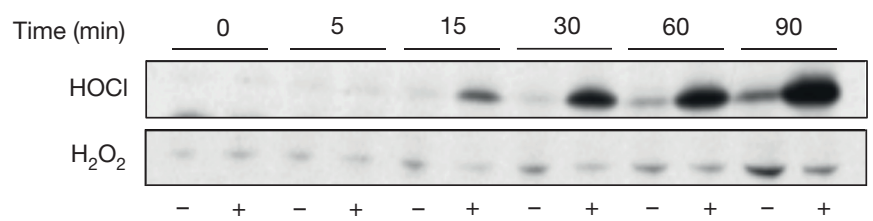

Figure 1 The MsrPQ system reduces free Met- $O$ and is induced by HOCl. a, JB590, a methionine auxotroph ( $\mathrm{Met}^{-}$, numbered ' 1 '), lacking all cytoplasmic Msrs ( $\mathrm{Met}^{-} \mathrm{Msr}^{-}$, ' 2 '), cannot grow on Met-O as the only Met source in contrast to suppressor BE100 ( $\mathrm{Met}^{-} \mathrm{Msr}^{-} \mathrm{Sup}^{\mathrm{Met}-\mathrm{O}^{+}}$, ' 3 '). Deletion of yed $Y$ (renamed msrP, '7'), moeA ('6') and tat $C$ (' 5 '), but not of $\operatorname{tr} x A$ ('4'), prevents the growth of BE100. b. The yedYZ operon is upregulated in BE100. The increase is observed both at the mRNA (quantitative PCR with reverse transcription (RT-qPCR), top; error bars, mean \pm s.e.m.; $n=3$ ) and protein (western blot, bottom) levels. The RT-qPCR primers were designed to quantify the yed $Y$-yed $Z$ mRNA. c, Immunoblot analysis showing that $\mathrm{HOCl}(2 \mathrm{mM})$, but not $\mathrm{H}_{2} \mathrm{O}_{2}$ $(1 \mathrm{mM})$, induces YedY synthesis in a wild-type strain. Images in $\mathbf{a}-\mathbf{c}$ are representative of experiments made in biological triplicate. Uncropped blots are in Supplementary Fig. 1.

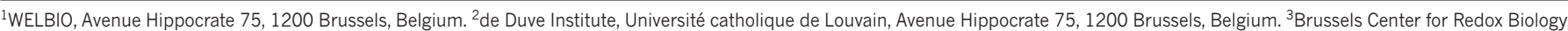
Avenue Hippocrate 75, 1200 Brussels, Belgium. ${ }^{4}$ Aix-Marseille Université, CNRS, Laboratoire de Chimie Bactérienne, UMR 7283, Institut de Microbiologie de la Méditerranée, 31 Chemin Joseph Aiguier, 13009 Marseille, France. ${ }^{5}$ Aix-Marseille Université, Centrale Marseille, CNRS, iSm2 UMR 7313, 13397, Marseille, France. †Present address: Department of Physics, Princeton University, Princeton, New Jersey 08544, USA.

*These authors contributed equally to this work. 


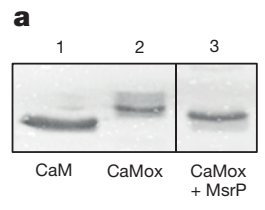

c
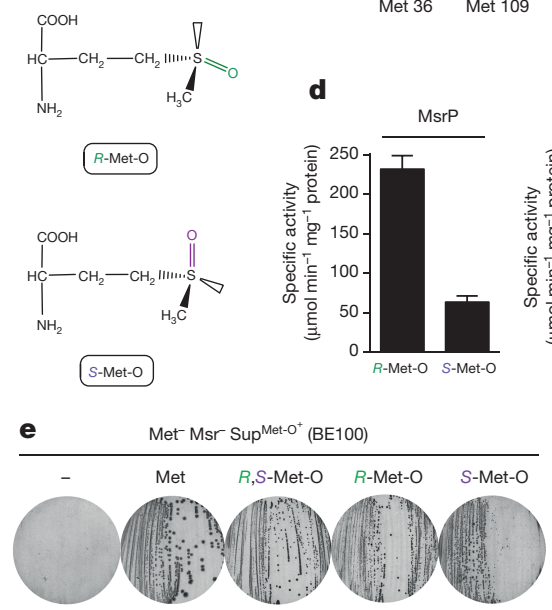

Figure 2 | MsrP non-stereospecifically reduces protein-bound Met-O. a, Oxidation of Met in calmodulin ( CaM) by $\mathrm{H}_{2} \mathrm{O}_{2}$ leads to a mobility shift of the oxidized protein (CaMox); compare lane 2 with lane 1. Incubation of CaMox with MsrP and a reducing system involving dithionite and benzyl viologen restores the mobility (lane 3). b, MsrP can reduce Met-O in CaMox. The oxidation state of peptides containing either Met36, Met109, Met124 or Met145-146 was determined by LC-MS/MS. Error bars, mean \pm s.e.m.; $n=4$ for Met36, 109 and 145-146; $n=5$ for Met124. Met-O residues were detected in the untreated and MsrP-treated samples owing to limitations inherent to the methodology applied and oxidation of the samples during analytical handling. c, Representation of the two diastereoisomers of Met-O, R-Met-O and S-Met-O. d, MsrP exhibits activity towards both diastereoisomers (left), contrary to the stereospecific enzymes MsrA and MsrB (right). Specific activities were assayed using $64 \mathrm{mM}$ of either $R$ - or $S$-Met-O. Error bars, mean \pm s.d.; $n=3$. e, The suppressor BE100 is able to grow on both isoforms of Met-O. Images in $\mathbf{a}$ and $\mathbf{e}$ are representative of experiments made in biological triplicate. The uncropped gel is in Supplementary Fig. 2.

be important for hypochlorous acid (HOCl) resistance ${ }^{7}$. We found that insertion of the IS2 led to a 100-fold increase in the levels of the yedYZ messenger RNA (mRNA) in strain BE100 and to higher YedY protein levels (Fig. 1b). Deletion of either yed $Y$ or yedZ prevented BE100 from growing on Met-O (Fig. 1a and Extended Data Table 1), while the simultaneous overproduction of YedY and YedZ, but not of YedY or YedZ alone, rendered the parental strain JB590 able to use Met-O (Extended Data Table 1). Altogether, these results indicated that the ability of the suppressor strain BE100 to reduce Met-O resulted from the increased synthesis of YedY and YedZ, implying that these two proteins function together as an Msr system. Growth of the BE100 strain was dependent on moeA, a gene required for the synthesis of molybdopterin cofactors, and on tat $C$, encoding a protein required for the translocation of metalloenzymes across the inner membrane (Fig. 1a). Exposure of wild-type cells to $\mathrm{HOCl}$, but not to $\mathrm{H}_{2} \mathrm{O}_{2}$, induced the synthesis of YedY to levels comparable to those observed in BE100 (Fig. 1c), indicating that these proteins are specifically expressed in response to bleach stress. Interestingly, induction by $\mathrm{HOCl}$ was dependent on the presence of a functional YedV/YedW system (Extended Data Fig. 1).

All previously identified Msrs rely on electrons derived from NADPH via the thioredoxin (Trx) system for activity ${ }^{1}$. This was not the case for YedYZ, as deletion of trxA, encoding the Trx responsible for Msr recycling ${ }^{8}$, had no effect on the ability of BE100 to reduce
Met-O (Fig. 1a). As YedZ contains a $b$-type haem ${ }^{9}$, a cofactor typically associated with the quinone-oxidizing cytochrome $b$ of the respiratory chain complexes, we considered the respiratory chain as a potential electron source. Deletion of menA and $u b i E$, two genes required for quinone synthesis, prevented BE100 from using Met-O (Extended Data Table 1), supporting a model in which YedZ uses electrons derived from the inner membrane pool of mature quinones to provide reducing equivalents to YedY (Extended Data Fig. 2). From now on, YedY and YedZ will be referred to as MsrP (for periplasm) and MsrQ (for quinone), respectively.

We then tested whether MsrPQ, in addition to free Met-O, also rescued Met-O residues present in proteins. Purified MsrP was shown to reduce $\mathrm{N}$-acetyl-Met-O, a substrate mimicking protein-bound Met-O (Extended Data Fig. 3a), with a Michaelis constant $\left(K_{\mathrm{m}}\right)$ of $3.8 \pm 1.2 \mathrm{mM}$, in line with the values reported for other $\mathrm{Msrs}^{10}$. Note that in the experiments involving purified MsrP, electrons were provided to the oxidoreductase by an inorganic system reducing molybdoenzymes $^{11}$. Next, we tested the ability of MsrP to reduce oxidized calmodulin (CaMox), a substrate commonly used to assess Msr activity. We used a gel shift assay based on the reduced mobility exhibited in SDS-polyacrylamide gel electrophoresis (SDS-PAGE) by proteins containing Met- $\mathrm{O}^{12}$. Incubation of CaMox with MsrP restored its mobility, suggesting that $\mathrm{MsrP}$ was able to reduce Met- $\mathrm{O}$ residues in CaMox (Fig. 2a). This was confirmed by showing with liquid chromatography-tandem mass spectrometry (LC-MS/MS) that the oxidized Met residues that could be detected in CaMox were reduced back to levels similar to those observed in CaM after incubation with MsrP (Fig. 2b). Altogether, these results indicated that MsrP is able to reduce protein-bound Met-O.

Upon oxidation, two diastereoisomers of Met-O can form, referred to as $R$ and $S$, owing to the asymmetric position of the oxidized sulfur atom in the lateral chain (Fig. 2c). All Msrs described so far exhibit stereospecificity, specifically reducing either the $R$ (MsrB, MsrC) or the $S$ isoform (MsrA, BisC). Using highly pure diastereoisomers (Extended Data Fig. 4), we found MsrP to exhibit activity towards both (Fig. 2 d), with $K_{\mathrm{m}}$ values of $25.7 \pm 4.7 \mathrm{mM}$ and $8.0 \pm 2.7 \mathrm{mM}$ for $R$ - and $S$-Met-O, respectively (Extended Data Fig. 3b). Accordingly, the BE100 suppressor strain was able to use $R$ - and $S$-Met-O (Fig. 2e), in contrast to strains expressing single stereospecific Msrs (Extended Data Fig. 3c). Thus, MsrP is a new type of Msr with no stereospecificity.

To search for the physiological substrates of MsrP, periplasmic proteins from a $\triangle m s r P$ mutant were oxidized with $\mathrm{HOCl}$, incubated with MsrP and subjected to a semi-quantitative two-dimensional LC-MS/MS analysis. Twenty proteins that had one or more $\mathrm{HOCl}$-oxidized Met residues that MsrP could reduce were identified (Extended Data Table 2). Using gel shift assays in combination with LC-MS/MS analysis, we confirmed the ability of MsrP to reduce the chaperone SurA and the lipoprotein Pal (Fig. 3a, b). Altogether, these results established that MsrP is able to repair a wide panel of structurally and functionally diverse periplasmic proteins in vitro.

SurA is the primary periplasmic chaperone, escorting most $\beta$-barrel proteins to the outer membrane $e^{13,14}$. As HOCl-oxidized SurA loses its chaperone activity (Fig. 4a), we used this property to probe the physiological importance of the MsrPQ system. First, we showed that SurA could be oxidized in vivo by $\mathrm{HOCl}$ and that expression of the MsrPQ system, but not of MsrP alone, restored its mobility (Fig. 3c). Similar results were obtained for Pal (Fig. 3d), confirming that MsrP and MsrQ collaborate in the protection of SurA and Pal from oxidative damage. We then tested if the repair of SurA by MsrP, which restores the activity of the chaperone in vitro (Fig. 4a), was important to keep SurA active under $\mathrm{HOCl}$ stress. For this, we used a mutant strain lacking the chaperone Skp, in which SurA becomes essential ${ }^{15,16}$. We found that deleting $m s r P$ rendered the $\Delta s k p$ strain hypersensitive to $\mathrm{HOCl}$ (Fig. $4 \mathrm{~b}$ ), suggesting that oxidized, inactive SurA accumulates in the absence of MsrP. In agreement with this, the sensitivity of the $\Delta s k p \Delta m s r P$ 
a

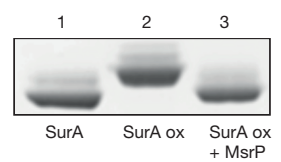

b
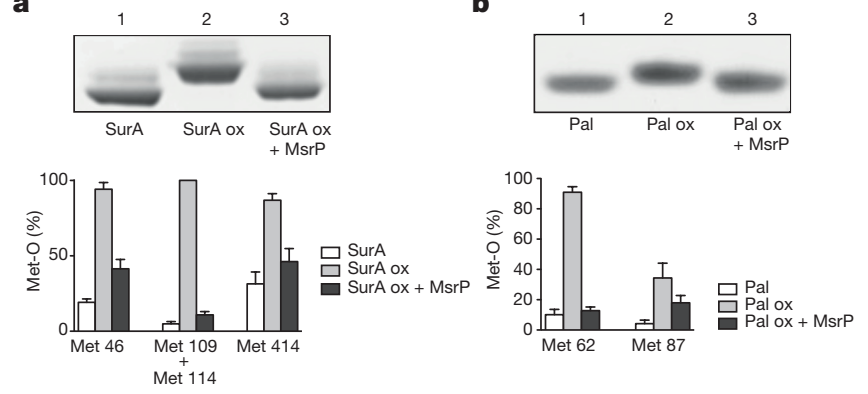

c
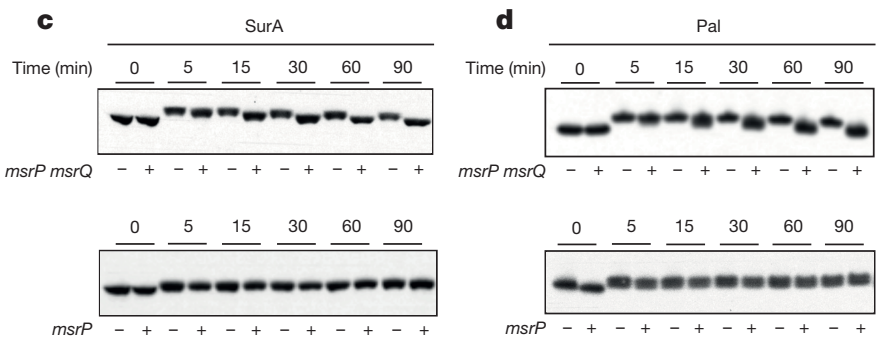

Figure 3 The MsrPQ system rescues oxidized Met residues in SurA and Pal. a, b, Oxidation of SurA (SurA ox) and Pal (Pal ox) by $\mathrm{H}_{2} \mathrm{O}_{2}$ leads to a mobility shift resulting from Met-O formation. Incubation with $\mathrm{MsrP}$ and the inorganic reducing system restores their mobility (top). The percentages of Met-O in the various samples were determined by LC-MS/MS analysis, confirming that MsrP reduces Met-O in SurA and $\mathrm{Pal}$ (bottom). Error bars, mean \pm s.e.m.; $n=3$. Met-O residues were detected in the untreated and MsrP-treated samples owing to limitations inherent to the methodology applied and oxidation of the samples during analytical handling. c, d, $\triangle m s r P Q$ cells carrying $m s r P$ either alone or with $m s r Q$ under an isopropyl $\beta$-D-1-thiogalactopyranoside (IPTG)inducible promoter on a plasmid (pAG192 and pAG195, respectively) were grown with IPTG $(100 \mu \mathrm{M})$. Cells were treated with chloramphenicol $\left(300 \mu \mathrm{g} \mathrm{ml}^{-1}\right)$ at an absorbance $\left(A_{600 \mathrm{~nm}}\right)$ of 0.5 to block new protein synthesis and $\mathrm{HOCl}(3.5 \mathrm{mM})$ was added. Synthesis of MsrP and MsrQ together (top), but not of MsrP alone (bottom), restores SurA and Pal mobility. Images in $\mathbf{a}-\mathbf{d}$ are representative of experiments made in biological triplicate. The small shift exhibited by SurA over time in the absence of MsrPQ could be due to a residual Msr activity, possibly an NADPH-dependent membrane-bound Msr activity previously detected ${ }^{21}$. Uncropped gels and blots are in Supplementary Fig. 3.

mutant to HOCl was suppressed by overexpression of SurA (Fig. 4c). Further highlighting the need to protect Met residues in periplasmic proteins, HOCl-pretreated $\triangle m s r P$ mutants were found to be more sensitive to SDS, a phenotype indicative of defects in the outer membrane (Fig. 4d) ${ }^{17}$.

The conservation of MsrPQ throughout Gram-negative bacteria (Extended Data Figs 5 and 6) illustrates the importance of having a Met-O reducing system in the periplasm. Neisseria species stand out as an exception in lacking MsrPQ. However, in these bacteria, evolutionary tinkering generated an envelope hybrid protein combining two classic stereospecific Msr domains ${ }^{18}$. A remarkable feature of MsrPQ is that its rescue activity depends on electrons provided by the respiratory chain. This represents an entirely novel way to provide reducing power for protein quality control in the envelope. Indeed, known reducing systems functioning in the periplasm use electrons provided by the inner membrane protein DsbD and $\operatorname{Tr} x^{19}$. Hence, diverting electrons from the respiratory chain to control extracytosolic protein quality is an unprecedented link between metabolism and cellular integrity.

The chaperone SurA is one of the targets of the MsrPQ system. Having a protein folding helper under the control of a repair system reveals an additional layer in the complex control network of periplasmic protein quality. Testing if this system is an attractive target for antimicrobial development, as suggested by the colonization defect exhibited by the $m s r P$ mutant in Campylobacter jejuni ${ }^{20}$, will be the a

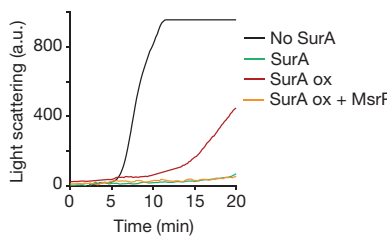

c

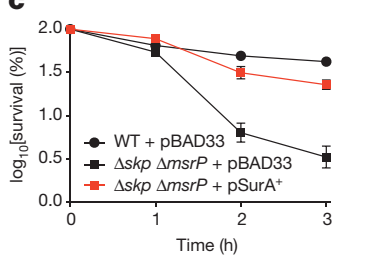

b

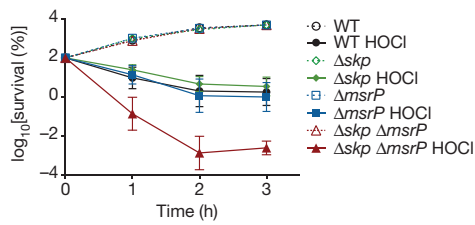

d

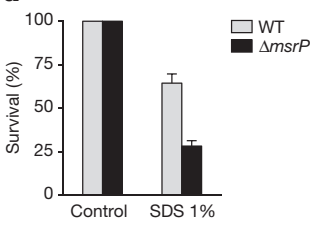

Figure 4 The reducing activity of the MsrPQ system is important for envelope integrity. a, Repair of oxidized SurA (SurA ox) by MsrP (SurA ox + MsrP) restores the ability of SurA to protect thermally unfolded citrate synthase from aggregation. The graph is representative of experiments made in biological triplicate (a.u., arbitrary units). b, While the wild-type (WT), the $\Delta s k p$ and the $\Delta m s r P$ strains are only moderately affected by exposure to $\mathrm{HOCl}(2 \mathrm{mM})$, the viability of the $\Delta s k p \Delta m s r P$ mutant (in which SurA is essential) is decreased. Error bars, mean \pm s.e.m.; $n=3$. c, The sensitivity of the $\Delta s k p \Delta m s r P$ mutant to $\mathrm{HOCl}$ is suppressed by SurA overexpression. Error bars, mean \pm s.e.m.; $n=4$. d, Pre-treatment with $\mathrm{HOCl}$ renders the $\triangle m s r P$ mutant hypersensitive to SDS, indicative of envelope defects. Error bars, mean \pm s.e.m.; $n=3$.

subject of future research. By highlighting the importance of protecting proteins targeted to oxidizing compartments, our work calls for a detailed investigation of the process of Met-O reduction in the endoplasmic reticulum, where only an $\mathrm{R}$-Met-O-specific MsrB has been identified ${ }^{3}$. As has long been speculated, a possibility would be that the endoplasmic reticulum contains an epimerase catalysing the interconversion of $R$ - and $S$-Met-O. Alternatively, in light of the present study, the endoplasmic reticulum could contain a novel Met-O reducing system yet to be discovered.

Online Content Methods, along with any additional Extended Data display items and Source Data, are available in the online version of the paper; references unique to these sections appear only in the online paper.

Received 12 March; accepted 30 September 2015.

Published online 7 December 2015.

1. Boschi-Muller, S., Gand, A. \& Branlant, G. The methionine sulfoxide reductases: catalysis and substrate specificities. Arch. Biochem. Biophys. 474, 266-273 (2008).

2. Ezraty, B., Aussel, L. \& Barras, F. Methionine sulfoxide reductases in prokaryotes. Biochim. Biophys. Acta 1703, 221-229 (2005).

3. Lee, B. C. \& Gladyshev, V. N. The biological significance of methionine sulfoxide stereochemistry. Free Radic. Biol. Med. 50, 221-227 (2011)

4. Urano, H., Umezawa, Y., Yamamoto, K., Ishihama, A. \& Ogasawara, H. Cooperative regulation of the common target genes between hydrogen peroxide-response YedVW and copper-response CusSR in Escherichia coli. Microbiology 161, 729-738 (2015)

5. Loschi, L. et al. Structural and biochemical identification of a novel bacterial oxidoreductase. J. Biol. Chem. 279, 50391-50400 (2004).

6. Workun, G. J., Moquin, K., Rothery, R. A. \& Weiner, J. H. Evolutionary persistence of the molybdopyranopterin-containing sulfite oxidase protein fold. Microbiol. Mol. Biol. Rev. 72, 228-248 (2008).

7. Melnyk, R. A. et al. Novel mechanism for scavenging of hypochlorite involving a periplasmic methionine-rich peptide and methionine sulfoxide reductase. MBio 6, e00233-15 (2015)

8. Stewart, E. J., Aslund, F. \& Beckwith, J. Disulfide bond formation in the Escherichia coli cytoplasm: an in vivo role reversal for the thioredoxins. EMBO J. 17, 5543-5550 (1998).

9. Brokx, S. J., Rothery, R. A., Zhang, G., Ng, D. P. \& Weiner, J. H. Characterization of an Escherichia coli sulfite oxidase homologue reveals the role of a conserved active site cysteine in assembly and function. Biochemistry 44, 10339-10348 (2005).

10. Tarrago, L. \& Gladyshev, V. N. Recharging oxidative protein repair: catalysis by methionine sulfoxide reductases towards their amino acid, protein, and model substrates. Biokhimiia 77, 1097-1107 (2012). 
11. Lowe, R. H. \& Evans, H. J. Preparation and some properties of a soluble nitrate reductase from Rhizobium japonicum. Biochim. Biophys. Acta $\mathbf{8 5}$ 377-389 (1964).

12. Le, D. T. et al. Analysis of methionine/selenomethionine oxidation and methionine sulfoxide reductase function using methionine-rich proteins and antibodies against their oxidized forms. Biochemistry 47, 6685-6694 (2008).

13. Silhavy, T. J., Kahne, D. \& Walker, S. The bacterial cell envelope. Cold Spring Harb. Perspect. Biol. 2, a000414 (2010)

14. Goemans, C., Denoncin, K. \& Collet, J. F. Folding mechanisms of periplasmic proteins. Biochim. Biophys. Acta 1843, 1517-1528 (2014).

15. Sklar, J. G., Wu, T., Kahne, D. \& Silhavy, T. J. Defining the roles of the periplasmic chaperones SurA, Skp, and DegP in Escherichia coli. Genes Dev. 21, 2473-2484 (2007).

16. Denoncin, K., Schwalm, J., Vertommen, D., Silhavy, T. J. \& Collet, J. F. Dissecting the Escherichia coli periplasmic chaperone network using differential proteomics. Proteomics 12, 1391-1401 (2012).

17. Ruiz, N., Falcone, B., Kahne, D. \& Silhavy, T. J. Chemical conditionality: a genetic strategy to probe organelle assembly. Cell 121, 307-317 (2005).

18. Brot, N. et al. The thioredoxin domain of Neisseria gonorrhoeae PilB can use electrons from DsbD to reduce downstream methionine sulfoxide reductases. J. Biol. Chem. 281, 32668-32675 (2006).

19. Cho, S. H. \& Collet, J. F. Many roles of the bacterial envelope reducing pathways. Antioxid. Redox Signal. 18, 1690-1698 (2013).

20. Hitchcock, A. et al. Roles of the twin-arginine translocase and associated chaperones in the biogenesis of the electron transport chains of the human pathogen Campylobacter jejuni. Microbiology 156, 2994-3010 (2010).

21. Spector, D., Etienne, F., Brot, N. \& Weissbach, H. New membrane-associated and soluble peptide methionine sulfoxide reductases in Escherichia coli. Biochem. Biophys. Res. Commun. 302, 284-289 (2003)
Supplementary Information is available in the online version of the paper.

Acknowledgements We thank A. Boujtat, G. Herinckx and J.-P. Szikora for technical and computational help and the members of the Barras and Collet laboratories for discussions. We are indebted to M. Sabaty and D. Pignol for sharing unpublished information, to T. Silhavy, T. Palmer, E. Bouveret and D. Hughes for providing strains and plasmids, to T. Lowther and M. Réglier for advice and discussions and to N. Typas, T. Mignot, J. Messens, J. Bardwell and F.-A. Wollman for reading the manuscript and providing comments. A.G. and J.S. are research fellows of the Fonds pour la formation à la Recherche dans I'Industrie et dans l'Agriculture, P.L. is 'Chargée de Recherche' and J.-F.C. is 'Maître de Recherche' of the Fonds de la Recherche Scientifique-FNRS (FRS-FNRS). E.O. is supported by a grant from the Indo-French Center for the Promotion of Advanced Research CEFIPRA '(5105-2)'. R.A. is supported by the Fonds Maurange, Fondation Roi Baudouin. This work was supported, in part, by grants from the FRS-FNRS and from the European Research Council (FP7/2007-2013) ERC independent researcher starting grant 282335-Sulfenic to J.-F.C. and funding by the Centre National de la Recherche Scientifique (CNRS), Fondation pour la Recherche Médicale (FRM) and Aix-Marseille Université to the F.B. team.

Author Contributions F.B., J.-F.C., A.G. and B.E. wrote the paper. A.G., B.E., C.H., A.V., L.E., J.-F.C. and F.B. designed and performed the experiments. A.G., B.E., C.H., J.B., P.L. and J.S. constructed the strains and cloned the constructs. F.B., J.-F.C., A.G., B.E. and C.H. analysed and interpreted the data. D.V. performed MS analyses. E.O. and O.I. prepared the diastereoisomers. R.A. performed bioinformatic analyses. Al authors discussed the results and commented on the manuscript.

Author Information Reprints and permissions information is available at www.nature.com/reprints. The authors declare no competing financial interests. Readers are welcome to comment on the online version of the paper. Correspondence and requests for materials should be addressed to F.B. (barras@imm.cnrs.fr) or J.-F.C. (jfcollet@uclouvain.be). 


\section{METHODS}

No statistical methods were used to predetermine sample size. The experiments were not randomized. The investigators were not blinded to allocation during experiments and outcome assessment.

Strains and microbial techniques. The strains used in this study are listed in Supplementary Table 1. Unless otherwise specified, for all deletion mutants, the corresponding alleles from the Keio collection ${ }^{22}$ were transferred into the MC4100 wild-type strain using P1 transduction standard procedures ${ }^{23}$ and checked by PCR. To excise the resistance cassette, we used pCP20 (refs 22, 24). Strain AG227, deleted for the entire yed $Y Z$ operon, was constructed as follows. First, a cat-sacB cassette, encoding chloramphenicol acetyl transferase and $\mathrm{SacB}$, a protein conferring sensitivity to sucrose, was amplified from strain $\mathrm{CH} 1990$ using primers yedYZ::cat-sacB_Fw and yedYZ::cat-sacB_Rv. The resulting PCR product shared a 40-base-pair (bp) homology to the $5^{\prime}$ untranslated region of yed $Y(m s r P)$ and to the $3^{\prime}$ untranslated region of $y e d Z(m s r Q)$ at its $5^{\prime}$ and $3^{\prime}$ ends, respectively. After purification, the PCR product was transformed by electroporation into $\mathrm{CH} 1940$. These cells harbour the pSIM5-tet vector, which encodes the Red recombination system proteins Gam, Beta and Exo under the control of the temperature-sensitive repressor cI859, encoded by the same vector. Induction of the Gam, Beta and Exo proteins was induced by shifting the cells to $42^{\circ} \mathrm{C}$ for $15 \mathrm{~min}$ before making them electrocompetent. Recombinant cells were selected on chloramphenicolcontaining plates $\left(25 \mu \mathrm{g} \mathrm{ml}^{-1}\right)$ at $37^{\circ} \mathrm{C}$ for $16 \mathrm{~h}$. At this temperature, the pSIM5-tet vector, which has a temperature-sensitive origin of replication, is lost. Colonies were also tested for the presence of the cat-sacB cassette by negative selection on sucrose-containing media ( $5 \%$ sucrose, no $\mathrm{NaCl}$ ). Finally, we verified that the $c a t-s a c B$ cassette replaced the $m s r P Q$ operon in the resulting strain (AG219) by sequencing across the junctions. The cat-sacB cassette was subsequently moved from AG219 to TP1004 by P1 transduction. The $c a t-s a c B$ cassette was eliminated from the resulting strain (AG220) by transforming it with the pSIM5-tet plasmid, electroporating it with the oligonucleotide Delta_yed YZ (300 ng) and performing lambda red recombination as described above. Recombinants were selected on sucrose-containing media at $30^{\circ} \mathrm{C}$ for $16 \mathrm{~h}$. To eliminate the plasmid, the selected colonies were grown at $37^{\circ} \mathrm{C}$ for $16 \mathrm{~h}$. Loss of the cassette in the resulting AG227 strain was verified by positive (sucrose resistance) and negative (chloramphenicol sensitivity) selection and by PCR.

The $m s r Q$ deletion mutant (strain BE105) was generated using the PCR knockout method developed in ref. 24. Briefly, a DNA fragment containing the cat gene flanked with the homologous sequences found upstream and downstream of the yedZ gene was PCR-amplified using pKD3 as template and the oligonucleotides P1_Up_YedZ and P2_Down_YedZ. Strain BE100, carrying plasmid pKD46, was then transformed by electroporation with the amplified linear fragment. Chloramphenicol-resistant clones were selected and verified by PCR.

The $m s r P:: l a c Z$ fusion was constructed using the method described in ref. 25 Briefly, the $m s r P$ promoter region lying between nucleotide -797 and nucleotide +63 , using the A nucleotide within the initiation triplet as a reference, was amplified by PCR with the appropriate oligonucleotides (lacI- $m s r P_{\text {forward }}$ and $l a c Z$ $m s r P_{\text {reverse }}^{\prime}$. Using mini-lambda-mediated recombineering, the PCR product was then directly recombined with the chromosome of a modified $E$. coli wild-type strain (PM1205), carrying a $\mathrm{P}_{\mathrm{BAD}}$-cat-sacB cassette inserted in front of lac $Z$, at the ninth codon. Recombinants were selected for loss of the $c a t-s a c B$ genes, resulting in the translational fusion of $m s r P$ to $l a c Z$.

Plasmid construction. The plasmids and primers used in this study are listed in Supplementary Tables 2 and 3, respectively. The YedY-His 6 (MsrP-His $\left.{ }_{6}\right)$ expression vector was constructed as follows. Site-directed mutagenesis using primers pTAC_NdeI_Fw and pTAC_NdeI_Rv was performed using pTAC-MAT-Tag-2 as template to introduce an NdeI restriction site in the vector, yielding vector pAG177. yed $Y(m s r P)$ DNA was amplified from the chromosome (MC4100) using primers pTAC_yed $Y \_F w$ and pTAC_yed $Y-\mathrm{His}_{6} \_\mathrm{Rv}$, which resulted in the fusion of a His tag coding sequence at the $3^{\prime}$ end. The PCR product was subsequently cloned into pAG177 using NdeI and BglII restriction sites, generating plasmid pAG178. To construct IPTG-inducible pTAC-MAT-Tag-2 vectors expressing either MsrP (without tag) or both MsrP and MsrQ, we first amplified the corresponding coding DNA sequences ( $m s r P$ or the $m s r P Q$ operon) from the chromosome of strain MC4100 using primer pairs pTAC_yedY_Fw/ pTAC_yedY_Rv and pTAC_yed $Y \_F w /$ pTAC yedZ Rv, respectively. The PCR products were then cloned into pAG177 using restriction sites NdeI and BglII, yielding pAG192 (MsrP) and pAG195 (MsrPQ). The complementation pAM238 vectors constitutively expressing either MsrP or MsrQ alone (without tag) or both MsrP and MsrQ were constructed as follows. We first amplified the corresponding coding DNA sequences ( $m s r P, m s r Q$ or the $m s r P Q$ locus) in addition to a $50 \mathrm{bp}$ upstream region from each start codon (to include a ribosomal binding site) from the chromosome of strain MG1655 using primer pairs pAM238_yedY_Fw/ pAM238_yedY_Rv, pAM238_yedZ_Fw/ pAM238_yedZ_Rv and pAM238_yedY_Fw/ pAM238_yedZ_Rv, respectively.
The PCR products were then cloned into pAM238 using restriction sites KpnI and PstI, yielding pAG264 (MsrP), pAG275 (MsrQ), and pAG265 (MsrPQ).

The vector allowing the arabinose-inducible expression of SurA was constructed as follows. The surA-encoding DNA and its $50 \mathrm{bp}$ upstream region (to include a ribosomal binding site) were amplified from the chromosome of strain MG1655 using the primer pair surA_Fw/surA_Rv. The PCR product was then cloned into pBAD33 using restriction sites KpnI and XbaI, yielding vector pAG290.

Analysis of the yedYZ operon expression by RT-qPCR. Expression levels of the yed $Y Z$ ( $m s r P Q)$ mRNA were assessed in M63 minimal medium supplemented with $0.5 \%$ glycerol, $0.15 \%$ casamino acids, $1 \mathrm{mM} \mathrm{MgSO}_{4}, 1 \mathrm{mM} \mathrm{MoNa}_{2} \mathrm{O}_{4}$, $17 \mu \mathrm{M} \mathrm{Fe}_{2}\left(\mathrm{SO}_{4}\right)_{3}$ and vitamins (thiamine $10 \mu \mathrm{g} \mathrm{ml}^{-1}$, biotin $1 \mu \mathrm{g} \mathrm{ml}^{-1}$, riboflavin $10 \mu \mathrm{g} \mathrm{ml}^{-1}$ and nicotinamide $10 \mu \mathrm{g} \mathrm{ml}^{-1}$ ). Overnight cultures of MG1655 were diluted to $A_{600 \mathrm{~nm}}=0.04$ in fresh $\mathrm{M} 63$ minimal medium $(100 \mathrm{ml})$ and cultured aerobically at $37^{\circ} \mathrm{C}$ until $A_{600 \mathrm{~nm}}=0.8$. Cells $(10 \mathrm{ml})$ were then pelleted, resuspended in TriPure (Roche) and homogenized. After mixing with chloroform, RNA was isolated by centrifugation $\left(15 \mathrm{~min}, 15,700 \mathrm{~g}, 4^{\circ} \mathrm{C}\right)$, precipitated with isopropanol, washed with ethanol 70\%, dried and finally resuspended in DEPC water. Any residual DNA was eliminated by treatment of the sample with DNase (Turbo DNA-free Kit, Ambion). A RevertAid RT kit (Thermo Scientific) was used to generate complementary DNA (cDNA) from $1 \mu \mathrm{g}$ RNA extracted from each of the cultured strains. cDNAs were then diluted $1 / 10$ and submitted to $\mathrm{qPCR}$, using a qPCR Core kit for SYBR Green I No ROX (Eurogentec) and a MyiQ SingleColour Real-Time PCR Detection System (Bio-Rad). Expression levels of yedYZ were normalized to the expression of gapA. Primers used for qPCR analysis were qPCR_yed $Y Z \_F w$ and qPCR_yed $Y Z \_R v$ for $y e d Y Z$, and qPCR_gapA_Fw and qPCR_gapA_Rv for gapA (Supplementary Table 3).

Immunoblot analysis of MsrP expression. Synthesis of MsrP in strains JB590 and BE100 was assessed as follows. Overnight cultures were diluted to $A_{600 \mathrm{~nm}}=0.04$ in fresh M63 minimal medium $(100 \mathrm{ml})$ and cultured aerobically at $37^{\circ} \mathrm{C}$ until $A_{600 \mathrm{~nm}}=0.8$. Nine hundred microlitres of each culture were then precipitated with $10 \%$ ice-cold trichloroacetic acid (TCA), pellets were washed with ice-cold acetone, dried, resuspended and heated at $95^{\circ} \mathrm{C}$ in Laemmli SDS sample buffer (SB buffer) ( $2 \%$ SDS, $10 \%$ glycerol, $60 \mathrm{mM}$ Tris- $\mathrm{HCl}$, pH 7.4, $0.01 \%$ bromophenol blue), and loaded on an SDS-PAGE gel for immunoblot analysis. The protein amounts loaded were standardized by taking into account the $A_{600} \mathrm{~nm}$ values of the cultures.

To monitor the MsrP expression levels after $\mathrm{NaOCl}$ or $\mathrm{H}_{2} \mathrm{O}_{2}$ treatment, overnight cultures of wild-type cells (MG1655) were diluted to $A_{600 \mathrm{~nm}}=0.04$ in fresh lysogeny broth (LB) medium $(100 \mathrm{ml})$ and grown aerobically at $37^{\circ} \mathrm{C}$ to $A_{600 \mathrm{~nm}}=0.5 . \mathrm{NaOCl}(2 \mathrm{mM})$ or $\mathrm{H}_{2} \mathrm{O}_{2}(1 \mathrm{mM})$ was then added to the cultures. Samples were TCA-precipitated, washed with ice-cold acetone, dried, suspended in SB buffer, heated at $95^{\circ} \mathrm{C}$ and loaded on an SDS-PAGE gel for immunoblot analysis. The protein amounts loaded were standardized by taking into account the $A_{600 \mathrm{~nm}}$ values of the cultures. The specificity of the anti-MsrP antibody was verified (Supplementary Fig. 5)

Preparation of pure diastereoisomeric forms of Met-O. L-Methionine sulfoxide $\left([\alpha]_{\mathrm{D}}{ }^{24}=+14.3^{\circ}\right.$ (water)), triethylamine $(>99 \%)$ and methanol $(>99.6 \%)$ were obtained from Sigma-Aldrich, picric acid from Prolabo and $\mathrm{D}_{2} \mathrm{O}$ from SDS. Water was purified using Millipore Elix Essential 3 apparatus. ${ }^{1} \mathrm{H}$ and ${ }^{13} \mathrm{C}$ NMR were recorded on a Bruker Avance III Nanobay spectrometer $\left({ }^{1} \mathrm{H}: 400 \mathrm{MHz} ;\left\{{ }^{1} \mathrm{H}\right\}{ }^{13} \mathrm{C}\right.$ $100 \mathrm{MHz})$. Chemical shifts $(\delta)$ were referenced to dioxane $\left({ }^{1} \mathrm{H}: \delta=3.75\right.$ p.p.m. ${ }^{13} \mathrm{C}: \delta=67.19$ p.p.m. ${ }^{26}$, which was added as an internal reference; resonances are detailed as follows: ${ }^{1} \mathrm{H}, \delta$ in parts per million (multiplicity, J-coupling in hertz, integration, signal attribution); $\left\{{ }^{1} \mathrm{H}{ }^{13} \mathrm{C}, \delta\right.$ in parts per million (signal attribution). For each diastereoisomer, chemical shifts are similar to those previously reported ${ }^{27}$ ${ }^{13} \mathrm{C}$ resonance assignments were confirmed by heteronuclear single quantum coherence experiments. Optical rotations were measured on an Anton Paar Modular Circular Polarimeter 200 instrument at $25^{\circ} \mathrm{C}$ and $589 \mathrm{~nm}$ from aqueous solution containing $0.8-1.2 \mathrm{~g}$ per $100 \mathrm{ml}$ of $\mathrm{L}$-methionine sulfoxide. The values reported are the average and s.d. relative to three independent measurements recorded on distinct solutions.

The commercial mixture of diastereoisomers was separated following the previously reported method ${ }^{28}$. Briefly, $10 \mathrm{ml}$ of water was added to L-methionine sulfoxide $(1.333 \mathrm{~g}, 8.069 \mathrm{mmol})$ and picric acid $(1.849 \mathrm{~g}, 8.071 \mathrm{mmol})$. The suspension was heated to reflux until complete dissolution and then slowly cooled to room temperature $\left(\sim 25^{\circ} \mathrm{C}\right)$. The suspension was filtered on a sintered funnel and the solid was washed with cold water $(10 \mathrm{ml}$ in total). Both the solid (dextro) and filtrate (levo) were collected separately for further purification.

Dextro. To the dried solid, $20 \mathrm{ml}$ of water were added and the mixture was heated to reflux then allowed to cool slowly to room temperature. The solid was filtered out, washed with $10 \mathrm{ml}$ water and dried. Again, $11 \mathrm{ml}$ of methanol were added to the resulting solid and the mixture heated to reflux. After slow cooling, the yellow crystals were filtered, washed with $5 \mathrm{ml}$ methanol and dried. A portion was used for structure determination by X-ray analysis. To the dextrogyre picrate 
salt (1.345g, $3.42 \mathrm{mmol}), \sim 1.1$ equivalents of triethylamine were added as a dilute aqueous solution $(22 \mathrm{ml}, 175 \mathrm{mM}, 3.85 \mathrm{mmol})$. Subsequently, $200 \mathrm{ml}$ of acetone were added portion-wise to the above stirring suspension and a white solid precipitated. This was filtered, washed, triturated with acetone and finally dried in vacuum $(533 \mathrm{mg}, 80 \%)$.

Levo. The volume of the filtrate was reduced in vacuum at $40^{\circ} \mathrm{C}$ to about $3-4 \mathrm{ml}$ to obtain a saturated solution and a small amount of precipitate. Then, $1.5 \mathrm{ml}$ of water were added, the suspension was filtered and the solid washed with minimal water $(2 \mathrm{ml})$. The whole step was repeated once (reduce the volume, dilute, filter and wash), and the resulting solution was then completely dried in vacuum. To the resulting yellow residue, $15 \mathrm{ml}$ of methanol were added and the suspension was heated to reflux. In our hands, no solid precipitated upon cooling (in contrast with the reported method $^{28}$ ); therefore the solution was dried again in vacuum. Following the same protocol as before, to the levogyre-enriched picrate salt $(1.354 \mathrm{~g}, 3.44 \mathrm{mmol}), \sim 1.1$ equivalents of triethylamine were added as a concentrated aqueous solution $(3.8 \mathrm{ml}, 1 \mathrm{M}, 3.8 \mathrm{mmol})$. Afterwards, $200 \mathrm{ml}$ of acetone were added portion-wise and a white solid precipitated. This was filtered, washed, triturated with acetone and finally dried in vacuum $(515 \mathrm{mg}, 77 \%)$.

Dextro (L-methionine-S-sulfoxide): $[\alpha]_{\mathrm{D}}{ }^{25}=+99.2 \pm 1.5^{\circ}$ (water); ${ }^{1} \mathrm{H}$ NMR $\left(400 \mathrm{MHz}, \mathrm{D}_{2} \mathrm{O} \mathrm{pD}=6.5\right): 3.88\left(\mathrm{t},{ }^{3} \mathrm{~J}=6.3,1 \mathrm{H}, \mathrm{H} \alpha_{\mathrm{S}}\right), 3.02\left(\mathrm{~m}, 2 \mathrm{H}, \mathrm{H} \gamma_{\mathrm{S}}\right), 2.74$ $\left(\mathrm{s}, 3 \mathrm{H}, \mathrm{H} \varepsilon_{\mathrm{s}}\right), 2.31\left(\mathrm{dd}, J=14.4,7.6,2 \mathrm{H}, \mathrm{H} \beta_{\mathrm{S}}\right) ;\left\{{ }^{1} \mathrm{H}\right\}^{13} \mathrm{C}$ NMR $\left(100 \mathrm{MHz}, \mathrm{D}_{2} \mathrm{O}\right)$ 173.8 $\left(\mathrm{COO}_{\mathrm{S}}\right), 54.0\left(\mathrm{C} \alpha_{\mathrm{S}}\right), 48.9\left(\mathrm{C} \gamma_{\mathrm{S}}\right), 37.2\left(\mathrm{C} \varepsilon_{\mathrm{S}}\right), 24.4\left(\mathrm{C} \beta_{\mathrm{S}}\right)$. Literature values from ref. 28: $[\alpha]_{\mathrm{D}}{ }^{25}=+99^{\circ}$ (water), from ref. $27:[\alpha]_{\mathrm{D}}=+98.2^{\circ}$ (water, room temperature); ${ }^{1} \mathrm{H}$ NMR $\left(300 \mathrm{MHz}, \mathrm{D}_{2} \mathrm{O}\right): 4.10(\mathrm{~m}, 1 \mathrm{H}), 3.08-2.78(\mathrm{~m}, 2 \mathrm{H}), 2.59(\mathrm{~s}, 3 \mathrm{H})$, 2.32-2.13 (m, 2H); ${ }^{13} \mathrm{C}$ NMR (75 MHz, $\left.\mathrm{D}_{2} \mathrm{O}\right): 171.1,52.0,48.3,37.0,23.5$.

Levo (L-methionine- $R$-sulfoxide): $[\alpha]_{\mathrm{D}}{ }^{25}=-72.7 \pm 0.5^{\circ}$ (water); ${ }^{1} \mathrm{H}$ NMR $\left(400 \mathrm{MHz}, \mathrm{D}_{2} \mathrm{O} \mathrm{pD}=6.5\right): 3.86\left(\mathrm{t},{ }^{3} J=6.3,1 \mathrm{H}, \mathrm{H} \alpha_{\mathrm{R}}\right), 3.12(\mathrm{ddd}, J=13.4,9.6,7.0$, $1 \mathrm{H}, \mathrm{H} \gamma_{\mathrm{R} 1}$ or $\left.\mathrm{H} \gamma_{\mathrm{R} 2}\right), 3.02\left(\mathrm{~m}, 2 \mathrm{H}, \mathrm{H} \gamma_{\mathrm{S}}\right), 2.93\left(\mathrm{ddd}, J=13.5,9.1,6.8,1 \mathrm{H}, \mathrm{H} \gamma_{\mathrm{R} 1}\right.$ or $\left.\mathrm{H} \gamma_{\mathrm{R} 2}\right), 2.74$ (s, 3H, H$\left.\varepsilon_{\mathrm{R}}\right), 2.31\left(\mathrm{~m}, 2 \mathrm{H}, \mathrm{H} \beta_{\mathrm{R}}\right) ;\left\{{ }^{1} \mathrm{H}\right\}{ }^{13} \mathrm{C} \mathrm{NMR}\left(100 \mathrm{MHz}, \mathrm{D}_{2} \mathrm{O}\right): 173.9$ $\left(\mathrm{COO}_{\mathrm{R}}\right), 54.2\left(\mathrm{C}_{\mathrm{R}}\right), 54.0\left(\mathrm{C} \alpha_{S}\right), 48.9\left(\mathrm{C} \gamma_{\mathrm{R}}\right), 37.2\left(\mathrm{C} \varepsilon_{S}\right), 37.0\left(\mathrm{C} \varepsilon_{\mathrm{R}}\right), 24.4\left(\mathrm{C} \beta_{\mathrm{R}}\right)$. Literature values from ref. $28:[\alpha]_{D}{ }^{26}=-71.6^{\circ}$ (water), from ref. 27: $[\alpha]_{D}=-78^{\circ}$ (water, room temperature); ${ }^{1} \mathrm{H}$ NMR $\left(300 \mathrm{MHz}, \mathrm{D}_{2} \mathrm{O}\right): 4.10(\mathrm{~m}, 1 \mathrm{H}), 3.08-2.78$ $(\mathrm{m}, 2 \mathrm{H}), 2.59(\mathrm{~s}, 3 \mathrm{H}), 2.32-2.13(\mathrm{~m}, 2 \mathrm{H}) ;{ }^{13} \mathrm{C}$ NMR $\left(75 \mathrm{MHz}, \mathrm{D}_{2} \mathrm{O}\right): 171.1,52.1$, $48.4,37.0,23.7$.

In the ${ }^{1} \mathrm{H}$ NMR spectra, the resonance centred at 3.02 p.p.m. was attributed to the $S$ - enantiomer. The relative integral values suggest that $R$-Met-O is contaminated by $3 \%$ of the $S$ - diastereoisomer. Moreover, comparing the measured $[\alpha]_{D}{ }^{25}$ values with those reported in ref. 27 , the data are consistent with the presence of $3 \% \mathrm{~S}$ - diastereoisomer as a contaminant. Such purity is in line with previous reports using the same separation method ${ }^{28,29}$. The absolute configuration of the $\mathrm{L}$-methionine-S-sulfoxide was confirmed by $\mathrm{X}$-ray structural analysis and matches previous assignments $\mathrm{s}^{27,30}$

Synthesis of $N$-acetyl-Met-O. To synthesize $N$-acetyl-Met-O, Met-O $(30 \mathrm{mg}$, Sigma-Aldrich) was solubilized in $2 \mathrm{ml} 100 \%$ acetic acid. After addition of $2 \mathrm{ml}$ of $97 \%$ acetic anhydride, the resulting mixture was incubated $2 \mathrm{~h}$ at $23^{\circ} \mathrm{C}$. Then, $2 \mathrm{ml}$ of water were added and the mixture was lyophilized overnight. Finally, the lyophilized $\mathrm{N}$-acetyl-Met-O was washed three times with $6 \mathrm{ml}$ of water, re-lyophilized and suspended in $500 \mathrm{mM} \mathrm{Na}_{2} \mathrm{HPO}_{4}, \mathrm{pH} 9.0$ to a final concentration of $1.5 \mathrm{M}$. The $\mathrm{pH}$ was then adjusted to 7 with $\mathrm{NaOH}$.

Kinetic analysis of MsrP activity. The MsrP reductase activity was followed spectrophotometrically at $600 \mathrm{~nm}$ by monitoring the substrate-dependent oxidation of reduced benzyl viologen, serving as an electron donor. Reactions were performed anaerobically at $30^{\circ} \mathrm{C}$ in degassed and nitrogen-flushed $50 \mathrm{mM}$ MOPS, pH 7.0 using stoppered cuvettes. Benzyl viologen was used at a final concentration of $0.4 \mathrm{mM}$ (molar extinction coefficient, $\varepsilon$, of reduced benzyl viologen $=7,800 \mathrm{M}^{-1} \mathrm{~cm}^{-1}$ ) and reduced with sodium dithionite. The final reaction volume was kept constant, with the ordered addition of benzyl viologen, sodium dithionite, 1-32 mM N-acetyl-methionine sulfoxide (NacMet-O) and $10 \mathrm{nM}$ MsrP-His ${ }_{6}$. The concentrations used for the $R$ - and S-Met-O diastereoisomers were $1-64 \mathrm{mM}$. The Michaelis-Menten parameters (maximum velocity $\left(V_{\max }\right)$ and $K_{\mathrm{m}}$ ) were determined using Graphpad Prism software.

Analysis of MsrA and MsrB activities. The reductase activities of MsrA and MsrB were followed spectrophotometrically at $340 \mathrm{~nm}$ by monitoring the substratedependent oxidation of NADPH $\left(\varepsilon=6,220 \mathrm{M}^{-1} \mathrm{~cm}^{-1}\right)$. Reactions were performed at $37^{\circ} \mathrm{C}$ in HEPES-KOH $20 \mathrm{mM}, \mathrm{pH} 7.4, \mathrm{NaCl} 10 \mathrm{mM}$, and the final reaction volumes were kept constant, with the ordered addition of $250 \mu \mathrm{M}$ NADPH (Roche), 2.6 $\mu \mathrm{M} \operatorname{TrxR}, 40 \mu \mathrm{M} \operatorname{Trx}, 64 \mathrm{mM}$ substrate and $1.5 \mu \mathrm{M}$ of either MsrA or MsrB.

Identification of the periplasmic proteins repaired by MsrP using twodimensional LC-MS/MS. The identification of the MsrP substrates was performed as follows. AG89 cells (2L) were grown aerobically at $37^{\circ} \mathrm{C}$ in terrific broth to $A_{600 \mathrm{~nm}}=0.8$. Periplasmic extracts were prepared as described previously ${ }^{31}$. Briefly, cells were pelleted by centrifugation at $3,000 \mathrm{~g}$ for $20 \mathrm{~min}$ at $4^{\circ} \mathrm{C}$ and incubated on ice with gentle shaking for $30 \mathrm{~min}$ in $100 \mathrm{mM}$ Tris- $\mathrm{HCl}$, $\mathrm{pH}$ 8.0, $20 \%$ sucrose, $1 \mathrm{mM}$ EDTA. This mixture also contained $20 \mathrm{mM} \mathrm{N}$-ethylmaleimide to alkylate reduced cysteine residues in proteins to prevent their subsequent oxidation. Periplasmic proteins were then isolated by centrifugation of the cells at $3,000 \mathrm{~g}$ for $20 \mathrm{~min}$ at $4{ }^{\circ} \mathrm{C}$. The periplasmic extract was subsequently concentrated by ultrafiltration in an Amicon cell (3,000 Da cutoff, YM-3 membrane) and loaded on a PD-10 column (GE Healthcare) equilibrated with $50 \mathrm{mM} \mathrm{NaPi}$, pH $8.0,50 \mathrm{mM} \mathrm{NaCl}$ After concentration using a $5 \mathrm{kDa}$ cutoff Vivaspin 4 (Sartorius) concentrator, the extract was finally separated in three samples. Two samples were incubated $10 \mathrm{~min}$ at $37^{\circ} \mathrm{C}$ with $2 \mathrm{mM} \mathrm{NaOCl}$ whereas the third was left untreated to serve as reduced control. $\mathrm{NaOCl}$ was then removed by gel filtration using a NAP- 5 column (GE Healthcare) equilibrated with $50 \mathrm{mM}$ MOPS, pH 7.0. The untreated sample was also subjected to the NAP-5 gel filtration.

One of the $\mathrm{NaOCl}$-oxidized fractions was then reduced in vitro by incubation for $1 \mathrm{~h}$ at $37^{\circ} \mathrm{C}$ with $10 \mu \mathrm{M}$ MsrP, $10 \mathrm{mM}$ benzyl viologen and an excess of sodium dithionite. The other $\mathrm{NaOCl}$-oxidized fraction, used as an oxidized control, and the non-oxidized fraction were incubated with $10 \mathrm{mM}$ benzyl viologen and an excess of sodium dithionite but without MsrP. The three samples were then de-salted by dialysis against $50 \mathrm{mM}$ MOPS, pH 7.0 by using Slide-A-Lyzer 3,500 MWCO G2 cassettes (Thermo Scientific). The three samples $(500 \mu \mathrm{g})$ were precipitated by adding TCA to a final concentration of $10 \% \mathrm{w} / \mathrm{v}$. The resulting pellets were washed with ice-cold acetone, dried in a Speedvac, suspended in $0.1 \mathrm{M} \mathrm{NH}_{4} \mathrm{HCO}_{3}$, $\mathrm{pH} 8.0$, digested overnight at $30^{\circ} \mathrm{C}$ with $3 \mu \mathrm{g}$ sequencing-grade trypsin, and analysed by two-dimensional LC-MS/MS essentially as described ${ }^{32}$. Briefly, peptides were first separated on a first-dimension hydrophilic interaction liquid chromatog raphy (HILIC) column with a reverse acetonitrile gradient and 25 fractions of $1 \mathrm{ml}$ collected ( 2 min per fraction). After drying, peptides were analysed by LC-MS/MS on a C18 column. The MS scan routine was set to analyse by MS/MS the five most intense ions of each full MS scan; dynamic exclusion was enabled to assure detection of co-eluting peptides.

Protein identification by mass spectrometry. Raw data collection of approximately 230,000 MS/MS spectra per two-dimensional LC-MS/MS experiment was followed by protein identification using SEQUEST. All MS raw files have been deposited in the ProteomeXchange Consortium ${ }^{33}$ via the PRIDE partner repository with the data set identifier PXD002804. In detail, peak lists were generated using extract-msn (ThermoScientific) within Proteome Discoverer 1.4.1. From raw files, MS/MS spectra were exported with the following settings: peptide mass range $350-5,000 \mathrm{Da}$; minimal total ion intensity 500 . The resulting peak lists were searched using SequestHT against a target-decoy E. coli protein database (release 07.01.2008, 8,678 entries comprising forward and reverse sequences) obtained from Uniprot. The following parameters were used: trypsin was selected with proteolytic cleavage only after arginine and lysine, number of internal cleavage sites was set to 1 , mass tolerance for precursors and fragment ions was 1.0 Da, and considered dynamic modifications were +15.99 Da for oxidized methionine and $+125.12 \mathrm{Da}$ for $\mathrm{N}$-ethylmaleimide on cysteines. Peptide matches were filtered using the $q$ value and posterior error probability calculated by the Percolator algorithm ensuring an estimated false positive rate below $5 \%$. The filtered SEQUEST HT output files for each peptide were grouped according to the protein from which they were derived using the multiconsensus results tool within Proteome Discoverer. Then the values of the spectral matches of only Met-containing peptides were combined from the three two-dimensional LC-MS/MS experiments and exported in a Microsoft Excel spreadsheet, with the rows referring to the peptide sequences and the columns to the fractions of the HILIC column. Oxidation of Met residues to Met-O by $\mathrm{NaOCl}$ causes a hydrophilic shift, which influences their retention time and makes them elute later (4-8 min) than their reduced counterpart on a HILIC column. If these Met-O are reduced by MsrP, they will then show a hydrophobic shift and elute at the same retention time on the HILIC column as in the control sample. By comparing the retention times and the number of peptide spectral matches of the Met-O-containing peptides in a periplasmic extract under three experimental conditions (control, oxidized by $\mathrm{NaOCl}$ with and without $\mathrm{MsrP}$ ), one can identify 'bona fide' potential MsrP substrates.

Protein expression and purification. TP1004 cells harbouring plasmid pAG178 and overexpressing $\mathrm{MsrP}^{-} \mathrm{His}_{6}$ protein were grown aerobically at $30^{\circ} \mathrm{C}$ in terrific broth (Sigma-Aldrich) supplemented with sodium molybdate $(1.5 \mathrm{mM})$ and ampicillin $\left(200 \mu \mathrm{g} \mathrm{ml}^{-1}\right)$. When cells reached $A_{600 \mathrm{~nm}}=0.8$, expression was induced with $0.1 \mathrm{mM}$ IPTG for $3 \mathrm{~h}$. Periplasmic proteins were then extracted as in ref. 32 . $\mathrm{MsrP}^{-\mathrm{His}_{6}}$ was $_{\text {then }}$ purified by loading the periplasmic extract on a $1 \mathrm{ml}$ HisTrap FF column (GE Healthcare) equilibrated with buffer A (NaPi $50 \mathrm{mM}, \mathrm{pH} 8.0, \mathrm{NaCl}$ $300 \mathrm{mM}$ ). After washing the column with buffer A, MsrP-His 6 was eluted by applying a linear gradient of imidazole (from 0 to $300 \mathrm{mM}$ ) in buffer A. The fractions containing $\mathrm{MsrP}^{-} \mathrm{His}_{6}$ were pooled, concentrated using a $5 \mathrm{kDa}$ cutoff Vivaspin 
15 (Sartorius) device and de-salted on a PD-10 column (GE Healthcare) equilibrated with $50 \mathrm{mM} \mathrm{NaPi}, \mathrm{pH} 8.0,150 \mathrm{mM} \mathrm{NaCl}$.

VU1 CaM, MsrA and MsrB were expressed and purified as described previously $^{34,35}$.

Trx was expressed and purified as follows. BL21 (DE3) cells harbouring plasmid pMD205, overexpressing Trx with a carboxy (C)-terminal His ${ }_{6}$ tag, were grown aerobically at $37^{\circ} \mathrm{C}$ in $\mathrm{LB}$ supplemented with kanamycin $\left(50 \mu \mathrm{g} \mathrm{ml}^{-1}\right)$. Expression was induced at $A_{600 \mathrm{~nm}}=0.6$ with $1 \mathrm{mM}$ IPTG for $3 \mathrm{~h}$. Cells were then pelleted, resuspended in buffer $\mathrm{A}(\mathrm{NaPi} 50 \mathrm{mM}, \mathrm{pH} 8.0, \mathrm{NaCl} 300 \mathrm{mM})$ and disrupted by two passes through a French pressure cell at 12,000 psi. The lysate was then centrifuged at $30,000 \mathrm{~g}$ and at $4{ }^{\circ} \mathrm{C}$ for $45 \mathrm{~min}$, to remove cell debris, and $\operatorname{Trx}$ was purified as described for $\mathrm{MsrP}^{-\mathrm{His}_{6}}$. Ni-NTA-purified Trx was then loaded on a $120 \mathrm{ml}$ HiLoad 16/60 Superdex 75 PG column (GE Healthcare) previously equilibrated with HEPES-KOH $50 \mathrm{mM}$, pH 7.4, $\mathrm{NaCl} 100 \mathrm{mM}$. The resulting Trx-containing fractions were pooled and concentrated using a $5 \mathrm{kDa}$ cutoff Vivaspin 15 device.

Thioredoxin reductase (TrxR) was expressed and purified as follows. BL21 (DE3) cells harbouring plasmid pPL223-2, overexpressing TrxR with an amino (N)-terminal $\mathrm{His}_{6}$ tag, were grown aerobically at $37^{\circ} \mathrm{C}$ in LB supplemented with ampicillin $\left(200 \mu \mathrm{g} \mathrm{ml}^{-1}\right)$. Expression was induced at $A_{600 \mathrm{~nm}}=0.6$ with $1 \mathrm{mM} \mathrm{IPTG}$ for $3 \mathrm{~h}$. Protein extraction was performed as described for Trx and purification was performed as described for MsrP-His 6 .

BL21 (DE3) cells harbouring plasmid pKD11, overexpressing SurA with a $\mathrm{C}$-terminal $\mathrm{His}_{6}$ tag, were grown aerobically at $37^{\circ} \mathrm{C}$ in $\mathrm{LB}$ supplemented with kanamycin $\left(50 \mu \mathrm{g} \mathrm{ml}^{-1}\right)$. Expression was induced at $A_{600 \mathrm{~nm}}=0.6$ with $1 \mathrm{mM} \mathrm{IPTG} \mathrm{for}$ $3 \mathrm{~h}$. Protein extraction and purification were performed as described for MsrP-His 6 .

MG1655 cells harbouring plasmid pKD84, overexpressing SurA with a C-terminal Strep-tag, were grown aerobically at $37^{\circ} \mathrm{C}$ in LB supplemented with ampicillin $\left(200 \mu \mathrm{g} \mathrm{ml}^{-1}\right)$. Expression was induced at $A_{600 \mathrm{~nm}}=0.7$ with a final concentration of $200 \mu \mathrm{gl}^{-1}$ anhydrotetracycline (AHT) for $5 \mathrm{~h}$. Protein extraction was performed as described for MsrP-His 6 . SurA-Strep was then purified by loading the periplasmic extract on a $5 \mathrm{ml}$ Strep-Tactin Superflow cartridge H-PR (IBA) equilibrated with buffer A (Tris- $\mathrm{HCl} 100 \mathrm{mM}, \mathrm{pH} 8.0, \mathrm{NaCl} 150 \mathrm{mM}$, EDTA $1 \mathrm{mM}$ ). After washing the column with buffer A, SurA-Strep was eluted by applying a linear gradient of desthiobiotin (from 0 to $2.5 \mathrm{mM}$ ) in buffer A. The fractions containing SurA-Strep were pooled, concentrated using a $5 \mathrm{kDa}$ cutoff Vivaspin 15 (Sartorius) device and de-salted on a PD-10 column (GE Healthcare) equilibrated with $50 \mathrm{mM}$ $\mathrm{NaPi}$, pH 8.0, $150 \mathrm{mM} \mathrm{NaCl}$.

A modified version of Pal lacking the signal sequence and in which the first cysteine of the lipobox was replaced by an alanine $\left(\mathrm{Pal}_{\mathrm{ClA}}\right)$ was expressed with an $\mathrm{N}$-terminal $\mathrm{His}_{6}$ tag from the pEB0513 vector in BL21 (DE3) cells. Cells were grown aerobically at $37^{\circ} \mathrm{C}$ in $\mathrm{LB}$ supplemented with ampicillin $\left(200 \mu \mathrm{g} \mathrm{ml}^{-1}\right)$ Expression was induced at $A_{600 \mathrm{~nm}}=0.6$ with $1 \mathrm{mM}$ IPTG for $3 \mathrm{~h}$. Protein extraction was performed as described for Trx and purification was performed as described for $\mathrm{MsrP}_{\mathrm{H}} \mathrm{His}_{6}$.

In vitro repair of oxidized CaM, SurA and Pal by MsrP. CaM was oxidized in vitro as described previously ${ }^{36}$. SurA- $\mathrm{His}_{6}$ and $\mathrm{Pal}$ were oxidized in vitro by incubating the purified proteins $(50 \mu \mathrm{M})$ for $2 \mathrm{~h} 30 \mathrm{~min}$ at $30^{\circ} \mathrm{C}$ with $100 \mathrm{mM} \mathrm{H}_{2} \mathrm{O}_{2}$ in a buffer containing $50 \mathrm{mM} \mathrm{NaPi}, \mathrm{pH} 8.0,50 \mathrm{mM} \mathrm{NaCl}$. $\mathrm{H}_{2} \mathrm{O}_{2}$ was then removed by gel filtration using a NAP- 5 column (GE Healthcare) equilibrated with $50 \mathrm{mM}$ $\mathrm{NaPi}, \mathrm{pH} 8.0,150 \mathrm{mM} \mathrm{NaCl}$.

In vitro repair of oxidized CaM (CaMox), SurA (SurA ox) and Pal (Pal ox) was assessed by incubating the oxidized proteins $(2 \mu \mathrm{M}$ of CaMox and SurA ox, $5 \mu \mathrm{M}$ of Pal ox) with purified $\mathrm{MsrP}^{-\mathrm{His}_{6}}(2 \mu \mathrm{M}$ for CaMox and SurA ox, $5 \mu \mathrm{M}$ for Pal ox), $10 \mathrm{mM}$ benzyl viologen and an excess of sodium dithionite at $37^{\circ} \mathrm{C}$ for $1 \mathrm{~h}$. As controls, the oxidized proteins were incubated separately with either MsrP-His or the inorganic reducing system (benzyl viologen and sodium dithionite). The reactions were stopped by adding SB buffer and heating at $95^{\circ} \mathrm{C}$ for the $\mathrm{CaM}$ and SurA samples or by adding $0.1 \%$ trifluoroacetic acid for the Pal samples. The CaM and SurA samples were then loaded on an SDS-PAGE gel and the proteins visualized with the PageBlue Protein Staining Solution (Fermentas). For the Pa samples $(20 \mu \mathrm{g})$, proteins were separated by reverse-phase high-performance liquid chromatography on a C4 column (Vydac 214TP54, $4.6 \mathrm{~mm} \times 250 \mathrm{~mm}$ ) at a flow rate of $400 \mu \mathrm{lmin}^{-1}$ with a linear gradient of acetonitrile in $0.1 \%$ trifluoroacetic acid ( $0-70 \%$ acetonitrile in $90 \mathrm{~min})$. Absorbance was monitored at $214 \mathrm{~nm}$ and the peaks were collected. The fractions were dried in a Speedvac and the proteins resupsended in $25 \mu \mathrm{l}$ of $100 \mathrm{mM} \mathrm{NH}_{4} \mathrm{HCO}_{3}$ before overnight digestion at $30^{\circ} \mathrm{C}$ with $0.5 \mu \mathrm{g}$ of trypsin or EndoGlu-C. The peptides were then analysed as described below.

For CaM and SurA, the gel bands corresponding to the different oxidation states were in-gel digested with trypsin and the resulting peptides analysed by LC-MS/MS on a C18 reverse-phase column as described above. Relative abundances of every Met-containing peptide in its different oxidation state were obtained by integration of peak area intensities, taking into account the extracted ion chromatogram of both doubly and triply charged ions.

In vivo repair of oxidized SurA and Pal by MsrP. The in vivo repair of SurA ox and Pal ox by the MsrPQ system or MsrP alone expressed from plasmids pAG195 and pAG192, respectively, was performed as follows. Overnight cultures of AG233 (containing the empty pAG177 vector), AG234 (containing the pAG195 plasmid) and AG289 (containing the pAG192 plasmid) were diluted to $A_{600 \mathrm{~nm}}=0.04$ into fresh $\mathrm{LB}$ medium $(100 \mathrm{ml})$ and cells were grown aerobically at $37^{\circ} \mathrm{C}$ in the presence of $0.1 \mathrm{mM}$ IPTG and $200 \mu \mathrm{g} \mathrm{ml}^{-1}$ ampicillin. At $A_{600 \mathrm{~nm}}=0.5$, cells were subjected to $\mathrm{NaOCl}$ treatment $(3.5 \mathrm{mM})$ and protein synthesis was blocked by the addition of chloramphenicol $\left(300 \mu \mathrm{g} \mathrm{ml}^{-1}\right)$. Samples were taken at different time point after $\mathrm{NaOCl}$ addition and precipitated with TCA. The pellets were then washed with ice-cold acetone, suspended in SB buffer, heated at $95^{\circ} \mathrm{C}$ and loaded on a SDS-PAGE gel for immunoblot analysis using anti-Pa ${ }^{37}$ and anti-SurA antibodies The specificity of the anti-SurA antibody was verified (Supplementary Fig. 6). The protein amounts loaded were standardized by taking into account the $A_{600 \mathrm{~nm}}$ values of the cultures.

Oxidation, repair and purification of SurA for analysis of chaperone function. SurA-Strep was oxidized in vitro by incubating the purified protein $(200 \mu \mathrm{M})$ for $3 \mathrm{~h}$ at $30^{\circ} \mathrm{C}$ with $100 \mathrm{mM} \mathrm{H}_{2} \mathrm{O}_{2}$ in a buffer containing $50 \mathrm{mM} \mathrm{NaPi}, \mathrm{pH} 8.0$ $150 \mathrm{mM} \mathrm{NaCl} . \mathrm{H}_{2} \mathrm{O}_{2}$ was then removed by gel filtration using a NAP- 5 column (GE Healthcare) equilibrated with $50 \mathrm{mM} \mathrm{NaPi}, \mathrm{pH} 8.0,150 \mathrm{mM} \mathrm{NaCl}$. For the in vitro repair of oxidized SurA (SurA ox), the oxidized protein $(30 \mu \mathrm{M})$ was incubated with purified $\mathrm{MsrP}^{-\mathrm{His}_{6}}(30 \mu \mathrm{M}), 10 \mathrm{mM}$ benzyl viologen and $10 \mathrm{mM}$ of sodium dithionite at $37^{\circ} \mathrm{C}$ for $1 \mathrm{~h}$. Following repair, SurA was purified by passing the sample through a gravity flow column containing $200 \mu 1$ Strep-Tactin Sepharose beads (from a $50 \%$ suspension, IBA), previously equilibrated with buffer A (Tris-HCl $100 \mathrm{mM}, \mathrm{pH} 8.0, \mathrm{NaCl} 150 \mathrm{mM}, \mathrm{EDTA} 1 \mathrm{mM}$ ). After washing with buffer A, repaired SurA was eluted using buffer A containing $2.5 \mathrm{mM}$ desthiobiotin. The elution fractions were pooled and submitted to buffer exchange using a NAP-5 column (GE Healthcare) equilibrated with $50 \mathrm{mM} \mathrm{NaPi}$, pH 8.0, $150 \mathrm{mM} \mathrm{NaCl}$. To check for the correct oxidation, repair and purification of SurA, samples were loaded on an SDS-PAGE gel and the proteins visualized with the PageBlue Protein Staining Solution (Fermentas).

Analysis of chaperone function. The ability of SurA to act as a chaperone preventing the thermal aggregation of citrate synthase (Sigma, reference C3260) was assessed as follows. The aggregation of citrate synthase $(0.15 \mu \mathrm{M})$ was monitored at $43^{\circ} \mathrm{C}$ in $40 \mathrm{mM}$ HEPES-KOH, pH 7.5, in the absence or in the presence of $0.6 \mu \mathrm{M}$ SurA, SurA ox or MsrP-repaired SurA ox using light-scattering measurements. To avoid effects that might have been caused by the protein buffer, all samples were added to the assay in constant volume. SurA ox and MsrP-repaired SurA ox were obtained as described above. Light-scattering measurements were made using a Varian Cary Eclipse spectrofluorometer both with excitation and with emission wavelengths set to $500 \mathrm{~nm}$ at a spectral bandwidth of $2.5 \mathrm{~nm}$. Data points were recorded every $0.1 \mathrm{~s}$

Genetic analysis of Met-O assimilation. The ability of various E. coli strains (BE100, JB08, CH193, BE104) to assimilate Met-O was assessed on M9 minimal medium supplemented with either Met or Met-O at $20 \mu \mathrm{g} \mathrm{ml}^{-1}$. Plates were incubated at $37^{\circ} \mathrm{C}$ for $72 \mathrm{~h}$. Overnight cultures of strains AG272, AG273, AG279 and AG274 were diluted to $A_{600 \mathrm{~nm}}=0.04$ into fresh M63 minimal medium $(100 \mathrm{ml})$ supplemented with $0.5 \%$ glycerol, $150 \mu \mathrm{g} \mathrm{ml}^{-1}$ of each amino acid, $1 \mathrm{mM} \mathrm{MgSO}_{4}$, $1 \mathrm{mM} \mathrm{MoNa}_{2} \mathrm{O}_{4}, 17 \mu \mathrm{M} \mathrm{Fe}_{2}\left(\mathrm{SO}_{4}\right)_{3}$, vitamins (thiamine $10 \mu \mathrm{g} \mathrm{ml}^{-1}$, biotin $1 \mu \mathrm{g} \mathrm{ml}^{-1}$, riboflavin $10 \mu \mathrm{g} \mathrm{ml}^{-1}$, and nicotinamide $10 \mu \mathrm{g} \mathrm{ml}^{-1}$ ) and $100 \mu \mathrm{g} \mathrm{ml}^{-1}$ spectinomycin, and grown aerobically at $37^{\circ} \mathrm{C}$. When $A_{600 \mathrm{~nm}}$ reached 0.5 , cells $(5 \mathrm{ml})$ were washed three times with M63 medium containing $150 \mu \mathrm{g} \mathrm{ml}^{-1}$ Met-O instead of methionine, and serially diluted in the same medium. Five microlitres of each dilution were then spotted on M63 plates containing either Met or Met-O at $150 \mathrm{\mu g} \mathrm{ml}^{-1}$, and plates were subsequently incubated at $37^{\circ} \mathrm{C}$ for $40 \mathrm{~h}$.

$\mathrm{HOCl}$ induction assays. The $m s r P::$ lacZ-containing strains $(\mathrm{CH} 183, \mathrm{CH} 186$ and $\mathrm{CH} 187$ ) were grown at $37^{\circ} \mathrm{C}$ with shaking in $\mathrm{M} 9$ minimal medium. When cells reached $A_{600 \mathrm{~nm}} \approx 0.2$, cultures were split into two plastic tubes, one of them containing $\mathrm{HOCl}(200 \mu \mathrm{M})$. These tubes were then incubated with an inclination of $90^{\circ}$ with shaking at $37^{\circ} \mathrm{C}$. After $30 \mathrm{~min}$ of incubation, $1 \mathrm{ml}$ was harvested and the bacteria were resuspended in $1 \mathrm{ml}$ of $\beta$-galactosidase buffer. Levels of $\beta$-galactosidase were measured as described ${ }^{38}$

HOCl survival assays. NR744, NR745, CH0127 and AG190 cells were grown aerobically at $37^{\circ} \mathrm{C}$ with shaking in $50 \mathrm{ml}$ of LB medium in $500 \mathrm{ml}$ flasks. When cells reached $A_{600 \mathrm{~nm}} \approx 0.45,5 \mathrm{ml}$ samples were transferred to conical polypropylene centrifuge tubes ( $50 \mathrm{ml}$; Sarstedt) and $\mathrm{HOCl}(2 \mathrm{mM})$ was added. Cells were then incubated at $37^{\circ} \mathrm{C}$ with shaking $\left(150\right.$ r.p.m.) at $90^{\circ}$ inclination. Samples were taken at various time points after stress, diluted in PBS buffer, spotted on LB agar and incubated at $37^{\circ} \mathrm{C}$ for $16 \mathrm{~h}$. Cell survival was determined by counting 
colony-forming units (c.f.u.) per millilitre. The absolute c.f.u. at time-point 0 (used as $100 \%$ ) was $\sim 10^{8}$ cells per millilitre in all experiments. For strains $\mathrm{CH} 194, \mathrm{CH} 196$ and $\mathrm{CH} 197$, the same protocol was used with chloramphenicol $\left(25 \mu \mathrm{g} \mathrm{ml}^{-1}\right)$ and arabinose $(0.2 \%)$ added to the cultures.

SDS survival assays. Cells (MG1655 and BE107) were grown at $37^{\circ} \mathrm{C}$ with shaking in $10 \mathrm{ml}$ of LB (in $100 \mathrm{ml}$ flasks). When cells reached $A_{600 \mathrm{~nm}} \approx 0.8,5 \mathrm{ml}$ samples were transferred to conical polypropylene centrifuge tubes $(50 \mathrm{ml}$, Sarstedt) and $\mathrm{HOCl}(2 \mathrm{mM})$ was added. After $5 \mathrm{~min}$ of incubation, samples were taken and diluted in PBS buffer to $\sim 2 \times 10^{3}$ cells per millilitre. Aliquots $(100 \mu \mathrm{l})$ were then spread on LB agar plates containing SDS (1\%). Colonies were counted the next day. Data set construction and phylogenetic analyses. A non-redundant local protein database containing 1,342 complete prokaryotic proteomes available in NCBI (http://www.ncbi.nlm.nih.gov/) as of 30 July 2014 was built. This database was queried with the BlastP program (default parameters) ${ }^{39}$, using YedY (NP_416480) and YedZ (NP_416481) of E. coli strain K-12 substrate MG1655 as a seed. Distinction between homologous and non-homologous sequences was assessed by visual inspection of each BlastP output (no arbitrary cut-off on the $E$ value or score). To ensure that we did not overlook divergent YedY or YedZ proteins, iterative BlastP queries were performed using homologues identified at each step as new seeds. The list of YedY and YedZ homologues is provided in Supplementary Data 1. The retrieved sequences were aligned using MAFFT version 7 (default parameters ${ }^{40}$; Supplementary Data 2 and 3). Each alignment was visually inspected and manually refined when necessary using the ED program from the MUST package ${ }^{41}$. Regions where the homology between amino-acid positions was doubtful were removed by using BMGE software (BLOSUM30 similarity matrix ${ }^{42}$ ).

For each homologue, the genomic context was investigated using MGcV (Microbial Genomic context Viewer ${ }^{43}$ ). The domain composition and protein location of each homologue was also analysed using pfam version 27.0 (ref. 44), SignalP version 4.1 (ref. 45) and TMHMM server version 2.0 (ref. 46), respectively.

For the YedY protein, preliminary phylogenetic analysis used FastTree version 2 and a gamma distribution with four categories ${ }^{47}$. On the basis of the resulting tree, the subfamily containing the sequence from $E$. coli was identified and selected for further phylogenetic investigations. The corresponding sequences were realigned using MAFFT version 7. The resulting alignment was trimmed with BMGE as previously described.

Maximum likelihood trees were computed using PHYML version 3.1 (ref. 48) with the Le and Gascuel model (amino-acid frequencies estimated from the data set) and a gamma distribution (four discrete categories of sites and an estimated alpha parameter) to take into account variations in evolutionary rate across sites. Branch robustness was estimated by the non-parametric bootstrap procedure implemented in PhyML (100 replicates of the original data set with the same parameters). Bayesian inferences were performed using MrBayes 3.2 (ref. 49) with a mixed model of amino-acid substitution including a gamma distribution (four discrete categories). MrBayes was run with four chains for one million generations and trees were sampled every 100 generations. To construct the consensus tree, the first 2,000 trees were discarded as 'burn in'.

22. Baba, T. et al. Construction of Escherichia coli K-12 in-frame, single-gene knockout mutants: the Keio collection. Mol Syst Biol 2, 2006.0008 (2006).

23. Bremer, E., Silhavy, T. J., Weisemann, J. M. \& Weinstock, G. M. Lambda placMu: a transposable derivative of bacteriophage lambda for creating lacZ protein fusions in a single step. J. Bacteriol. 158, 1084-1093 (1984).

24. Datsenko, K. A. \& Wanner, B. L. One-step inactivation of chromosomal genes in Escherichia coli K-12 using PCR products. Proc. Natl Acad. Sci. USA 97, 6640-6645 (2000)

25. Mandin, P. \& Gottesman, S. A genetic approach for finding small RNAs regulators of genes of interest identifies RybC as regulating the $\mathrm{DpiA} / \mathrm{DpiB}$ two-component system. Mol. Microbiol. 72, 551-565 (2009).
26. Gottlieb, H. E., Kotlyar, V. \& Nudelman, A. NMR chemical shifts of common laboratory solvents as trace impurities. J. Org. Chem. 62, 7512-7515 (1997).

27. Holland, H. L., Andreana, P. R. \& Brown, F. M. Biocatalytic and chemical routes to all the stereoisomers of methionine and ethionine sulfoxides. Tetrahedron Asymm. 10, 2833-2843 (1999).

28. Lavine, T. F. The formation, resolution, and optical properties of the diastereoisomeric sulfoxides derived from I-methionine. J. Biol. Chem. 169, 477-491 (1947)

29. Koc, A., Gasch, A. P., Rutherford, J. C., Kim, H. Y. \& Gladyshev, V. N. Methionine sulfoxide reductase regulation of yeast lifespan reveals reactive oxygen species-dependent and -independent components of aging. Proc. Natl Acad. Sci. USA 101, 7999-8004 (2004).

30. Lherbet, C., Gravel, C. \& Keillor, J. W. Synthesis of S-alkyl I-homocysteine analogues of glutathione and their kinetic studies with $\gamma$-glutamyl transpeptidase. Bioorg. Med. Chem. Lett. 14, 3451-3455 (2004).

31. Vertommen, D. et al. The disulphide isomerase DsbC cooperates with the oxidase DsbA in a DsbD-independent manner. Mol. Microbiol. 67, 336-349 (2008).

32. Arts, I. S. et al. Dissecting the machinery that introduces disulfide bonds in Pseudomonas aeruginosa. MBio 4, e00912-13 (2013).

33. Vizcaíno, J. A. et al. ProteomeXchange provides globally co-ordinated proteomics data submission and dissemination. Nature Biotechnol. 30, 223-226 (2004).

34. Roberts, D. M. et al. Chemical synthesis and expression of a calmodulin gene designed for site-specific mutagenesis. Biochemistry 24, 5090-5098 (1985)

35. Grimaud, R. et al. Repair of oxidized proteins. Identification of a new methionine sulfoxide reductase. J. Biol. Chem. 276, 48915-48920 (2001).

36. Tsvetkov, P. O. et al. Calorimetry and mass spectrometry study of oxidized calmodulin interaction with target and differential repair by methionine sulfoxide reductases. Biochimie 87, 473-480 (2005).

37. Cascales, E., Bernadac, A., Gavioli, M., Lazzaroni, J. C. \& Lloubes, R. Pal lipoprotein of Escherichia coli plays a major role in outer membrane integrity. J. Bacteriol. 184, 754-759 (2002).

38. Miller, J. A Short Course in Bacterial Genetics Unit 3, 72-74 (Cold Spring Harbor Laboratory Press, 1992).

39. Altschul, S. F. et al. Gapped BLAST and PSI-BLAST: a new generation of protein database search programs. Nucleic Acids Res. 25, 3389-3402 (1997).

40. Katoh, K. \& Standley, D. M. MAFFT multiple sequence alignment software version 7: improvements in performance and usability. Mol. Biol. Evol. 30, 772-780 (2013)

41. Philippe, H. MUST, a computer package of Management Utilities for Sequences and Trees. Nucleic Acids Res. 21, 5264-5272 (1993).

42. Criscuolo, A. \& Gribaldo, S. BMGE (Block Mapping and Gathering with Entropy): a new software for selection of phylogenetic informative regions from multiple sequence alignments. BMC Evol. Biol. 10, 210 (2010).

43. Overmars, L., Kerkhoven, R., Siezen, R. J. \& Francke, C. MGcV: the microbial genomic context viewer for comparative genome analysis. BMC Genomics 14, 209 (2013)

44. Finn, R. D. et al. Pfam: the protein families database. Nucleic Acids Res. $\mathbf{4 2}$, D222-D230 (2014)

45. Petersen, T. N., Brunak, S., von Heijne, G. \& Nielsen, H. SignalP 4.0: discriminating signal peptides from transmembrane regions. Nature Methods 8, 785-786 (2011).

46. Sonnhammer, E. L., von Heijne, G. \& Krogh, A. A hidden Markov model for predicting transmembrane helices in protein sequences. Proc. Int. Conf. Intell. Syst. Mol. Biol. 6, 175-182 (1998).

47. Price, M. N., Dehal, P. S. \& Arkin, A. P. FastTree 2 - approximately maximumlikelihood trees for large alignments. PLoS One 5, e9490 (2010).

48. Guindon, S. et al. New algorithms and methods to estimate maximumlikelihood phylogenies: assessing the performance of PhyML 3.0. Syst. Biol. 59, 307-321 (2010)

49. Ronquist, F. et al. MrBayes 3.2: efficient Bayesian phylogenetic inference and model choice across a large model space. Syst. Biol. 61, 539-542 (2012). 

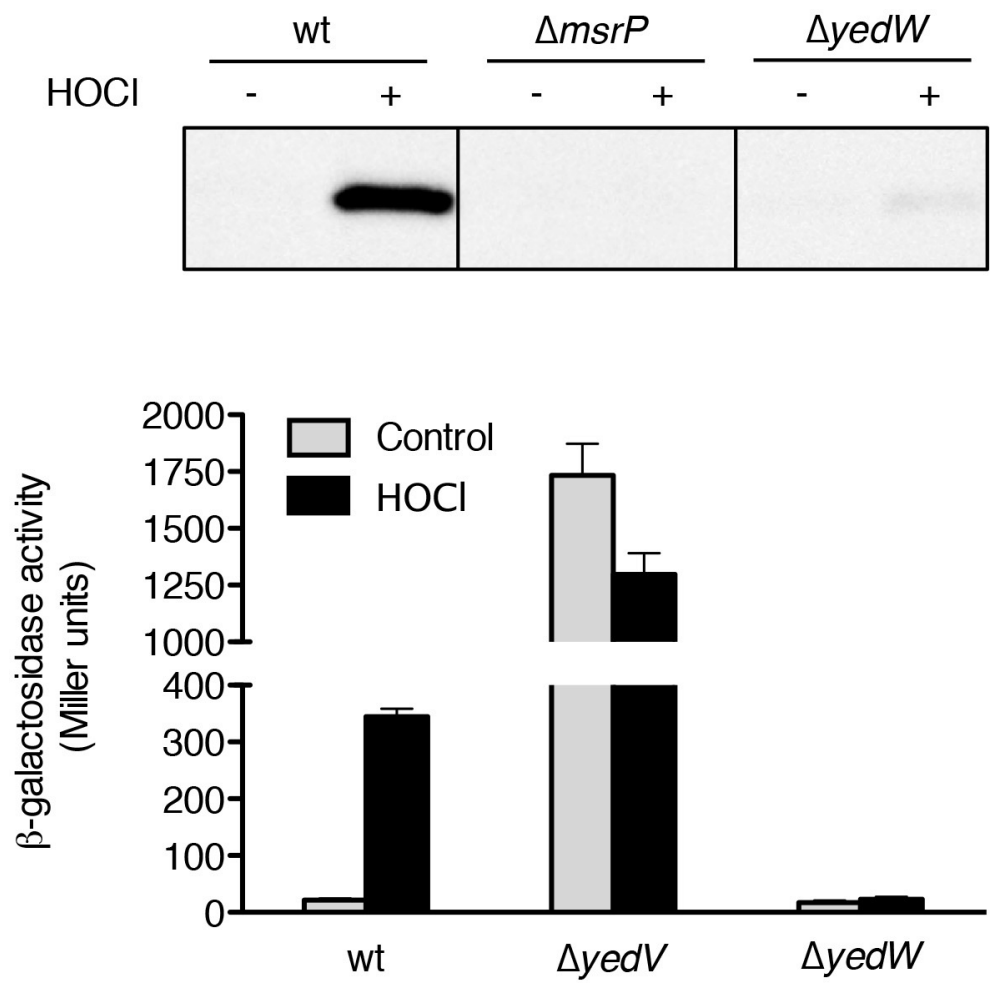

Extended Data Figure 1 | Induction of MsrPQ by $\mathrm{HOCl}$ is dependent on the presence of a functional YedVW two-component system. Top, immunoblot analysis shows that the induction of MsrP synthesis by $\mathrm{HOCl}$ $(0.2 \mathrm{mM})$ is yed $W$-dependent. The image is representative of experiments made in biological triplicate. Bottom, an $m s r P::$ lac $Z$ fusion was used as a read-out for $m s r P$ expression. Deletion of $y e d V$ upregulates $m s r P$ expression, while deletion of yed $W$ prevents its induction by $\mathrm{HOCl}$. Error bars,

mean \pm s.e.m.; $n=4$. The uncropped blot is shown in Supplementary Fig. 4 . 


\section{RESEARCH LETTER}

\section{Extracellular environment}

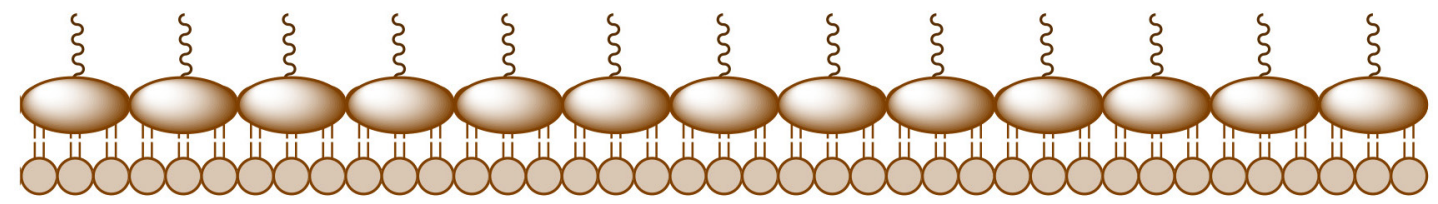

Outer membrane

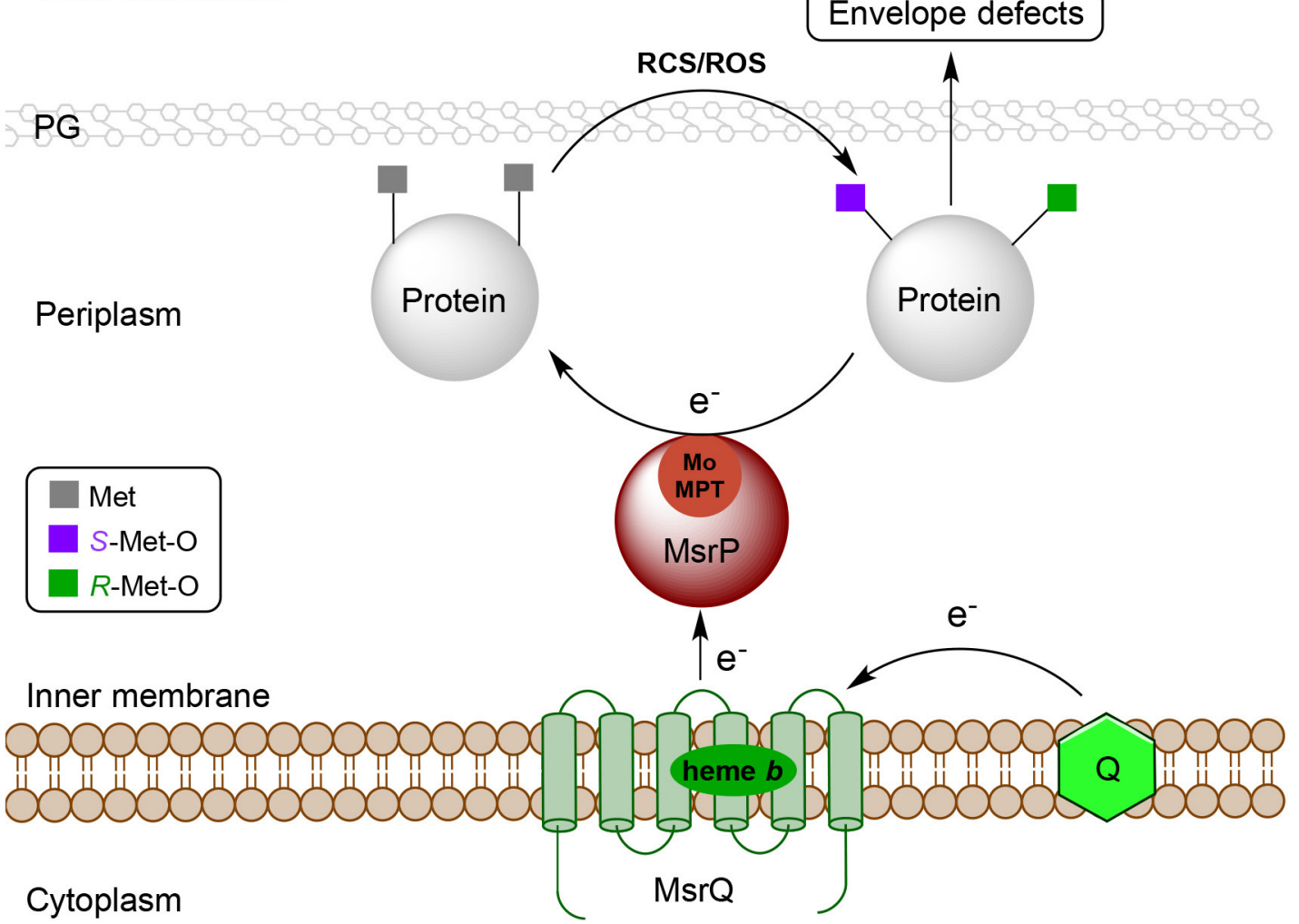

Extended Data Figure $2 \mid$ Respiratory chain-powered, nonstereospecific reduction of Met-O in periplasmic proteins by the MsrPQ system maintains envelope integrity. Upon exposure to reactive species of chlorine (RCS) and/or reactive species of oxygen (ROS), methionine residues (Met) in periplasmic proteins such as SurA and Pal get oxidized and randomly form either the $R$ - or the $S$ - diastereoisomer of Met-O. This results in the loss of function of some proteins important for maintaining the integrity of the envelope, such as SurA, giving rise to envelope defects. MsrP catalyses the reduction of both diastereoisomers of Met-O with the help of its molybdenum-molybdopterin (Mo-MPT) cofactor. Electrons for reduction are provided by the quinone $(\mathrm{Q})$ pool of the respiratory chain through MsrQ, the inner membrane haem $b$-containing partner of MsrP. PG, peptidoglycan. 
a

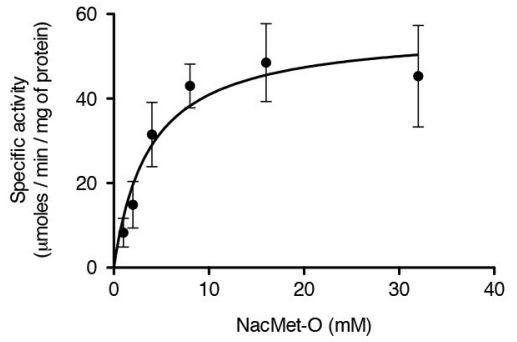

c

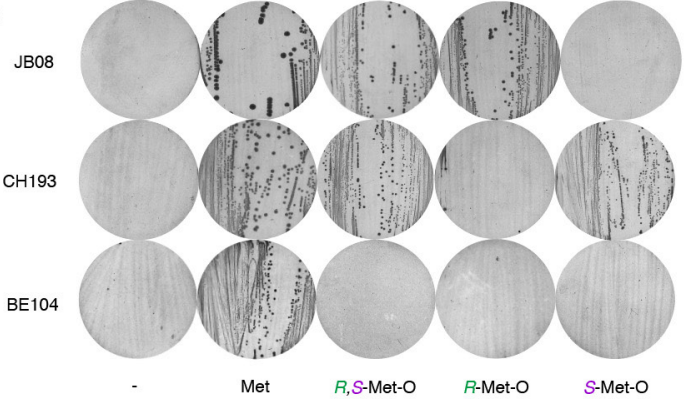

Extended Data Figure $3 \mid$ MsrP non-stereospecifically reduces Met-O. a, MsrP reduces $\mathrm{N}$-acetyl-Met-O (NacMet-O), a substrate mimicking protein-bound Met- $\mathrm{O}$, with $K_{\mathrm{m}}=3.8 \pm 1.2 \mathrm{mM}$, turnover number $\left(k_{\text {cat }}\right)=30.5 \pm 3.1 \mathrm{~s}^{-1}$ and $V_{\max }=56.3 \pm 5.8 \mu \mathrm{mol} \mathrm{min}^{-1}$ per milligram protein (error bars, mean \pm s.d.; $n=3$ ). $\mathbf{b}, \mathrm{MsrP}$ is a non-stereospecific Msr, being able to reduce both $S$-Met-O (with $K_{\mathrm{m}}=8.0 \pm 2.7 \mathrm{mM}$, $k_{\text {cat }}=36.0 \pm 3.6 \mathrm{~s}^{-1}$ and $V_{\max }=67.2 \pm 6.4 \mu \mathrm{mol} \mathrm{min}^{-1}$ per milligram protein) and $R$-Met-O (with $K_{\mathrm{m}}=25.7 \pm 4.7 \mathrm{mM}, k_{\text {cat }}=168.3 \pm 15.0 \mathrm{~s}^{-1}$ and $V_{\max }=313.4 \pm 27.6 \mu \mathrm{mol} \mathrm{min}^{-1}$ per milligram protein). Error bars, mean \pm s.d.; $n=3$. c, Strain JB08 $\left(\mathrm{Met}^{-} \mathrm{MsrA}^{-} \mathrm{MsrB}^{-} \mathrm{BisC}^{-}\right.$, producing $\mathrm{MsrC}$ ) is able to grow only on $\mathrm{R}$-Met- $\mathrm{O}$, whereas strain $\mathrm{CH} 193$ b

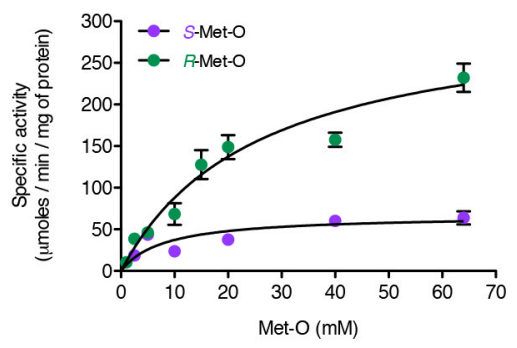

d

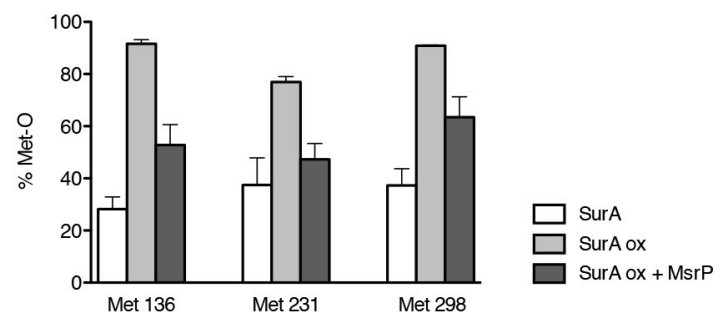

(Met ${ }^{-} \mathrm{MsrA}^{-} \mathrm{MsrB}^{-} \mathrm{MsrC}^{-}$, producing BisC) in only able to grow on $S$-Met-O. Deletion of $m s r P$ in strain BE100 ( $\mathrm{Met}^{-} \mathrm{Msr}^{-} \mathrm{Sup}^{\mathrm{Met}-\mathrm{O}^{+}}$) prevents its growth on $R$ - and $S$-Met-O (strain BE104 $=\mathrm{Met}^{-} \mathrm{Msr}^{-}$ $\mathrm{Sup}^{\mathrm{Met}-\mathrm{O}^{+}} \Delta m s r P$, compare with growth of BE100 in Fig. 2e). Images are representative of experiments made in biological triplicate. $\mathbf{d}$, The periplasmic chaperone SurA was treated with $\mathrm{H}_{2} \mathrm{O}_{2}$, giving rise to SurA ox, a sample of which was subsequently incubated with MsrP and the inorganic reducing system in vitro. The oxidation state of specific Met residues (Met 136, 231 and 298) in the various samples was determined by LC-MS/MS analysis. Error bars, mean \pm s.e.m.; $n=4$. 
a

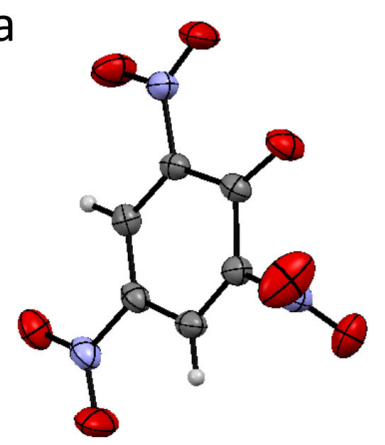

C

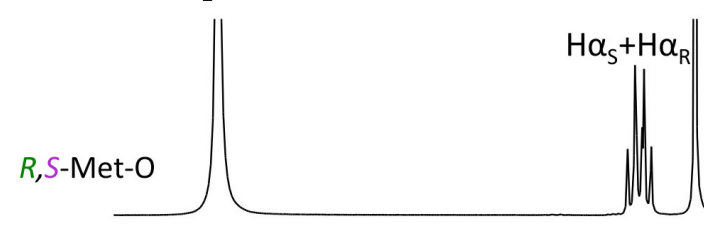

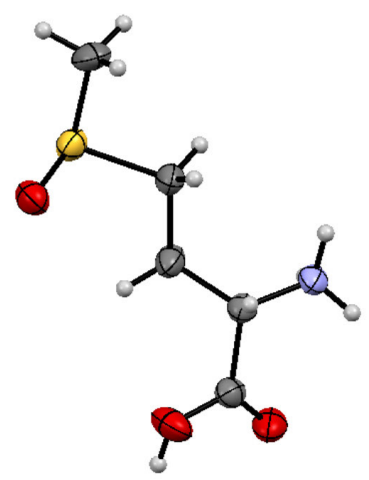

dioxane
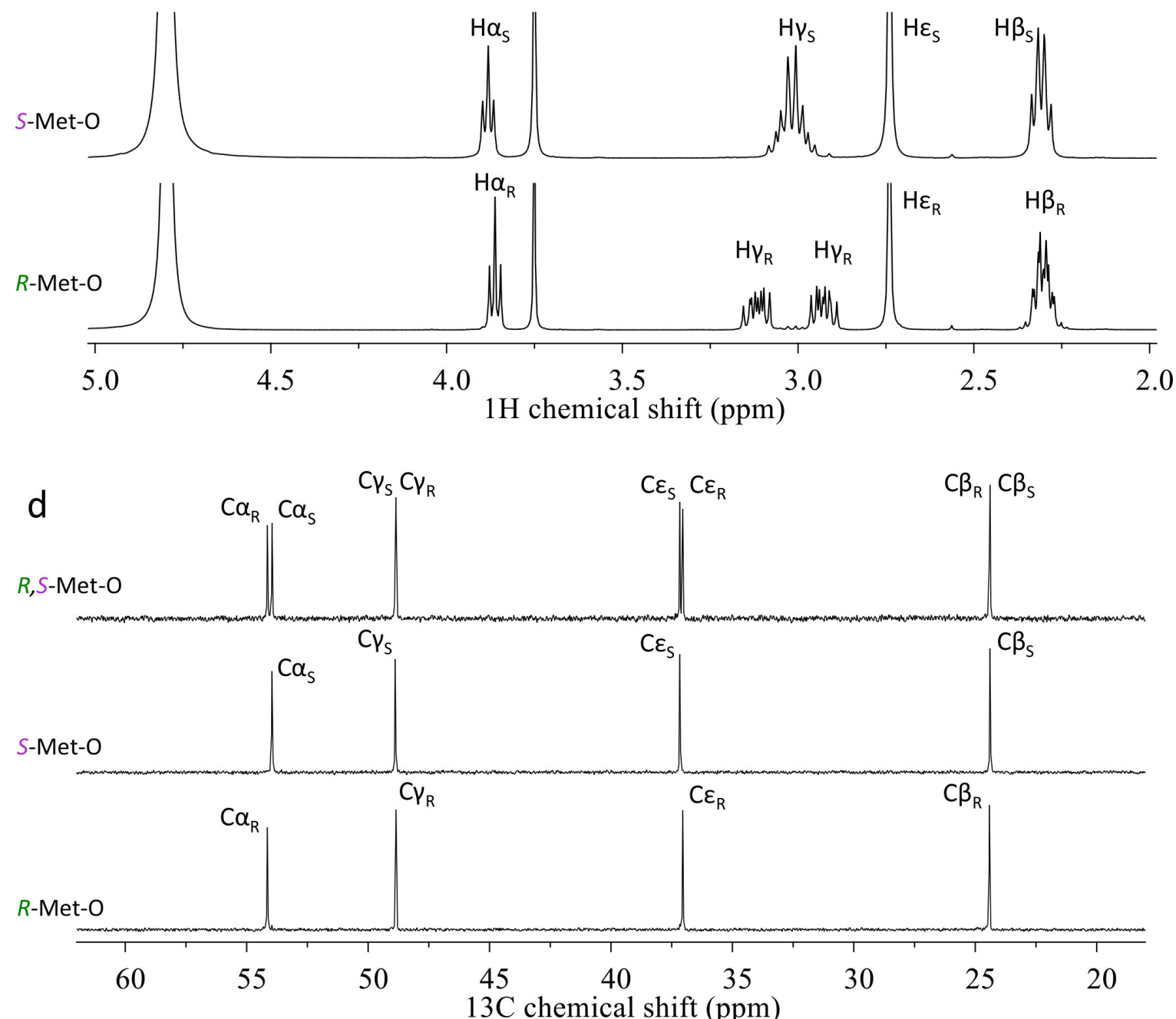

Extended Data Figure 4 Preparation of pure diastereoisomeric forms of Met-O. a, The Oak Ridge Thermal Ellipsoid Plot (ORTEP ellipsoid) representation with $50 \%$ probability level of the crystal structure for the isolated salt of L-methionine-S-sulfoxide (right) picrate (left). The grey, blue, red, white and yellow spheres respectively represent carbon, nitrogen, oxygen, hydrogen and sulfur atoms. b, Chemdraw representation of $\mathrm{L}$-methionine- $R, S$-sulfoxide with proton and carbon positioning (relative to NMR assignment). c, Zoom on the ${ }^{1} \mathrm{H}$ NMR spectra of $\sim 150 \mathrm{mM}$ solutions $b$

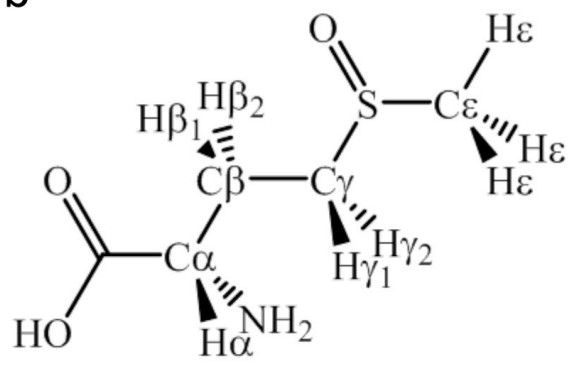




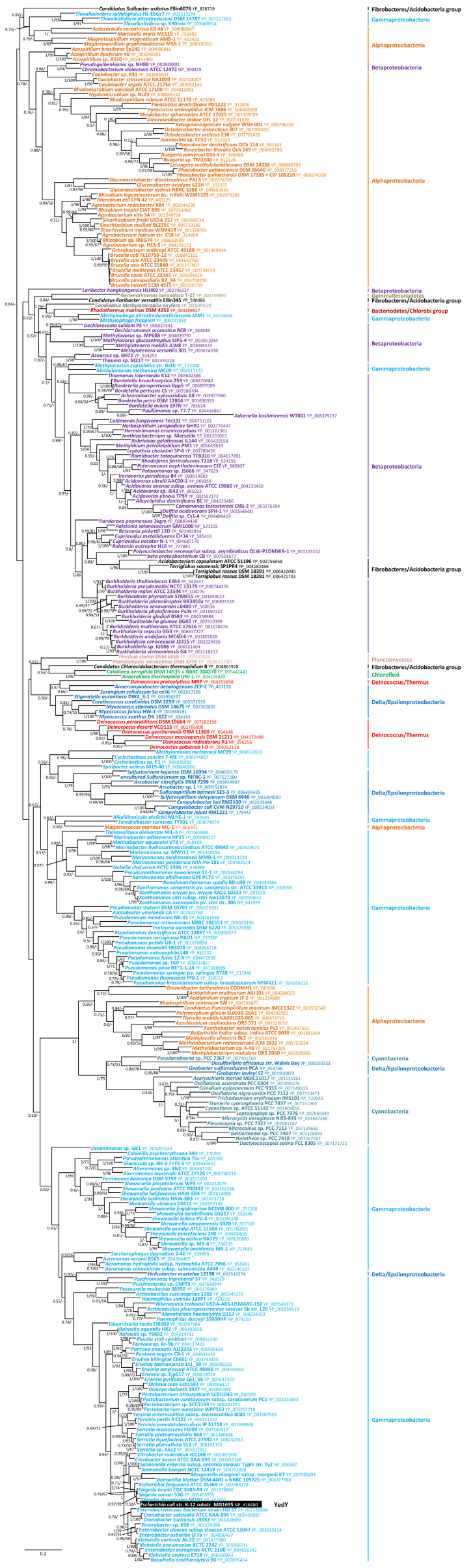




\section{RESEARCH LETTER}

Extended Data Figure 5 | Individual phylogenies of YedY. Shown are unrooted Bayesian phylogenetic trees for YedY (b1971, 310 sequences, 260 positions). Numbers at nodes indicate posterior probabilities computed by MrBayes ${ }^{49}$ and bootstrap values computed by PhyML ${ }^{48}$.
Only posterior probabilities and bootstrap values above 0.5 and $50 \%$, respectively, are shown. Scale bars, average number of substitutions per site. In the phylogenetic tree, YedY from E. coli is highlighted in grey. 


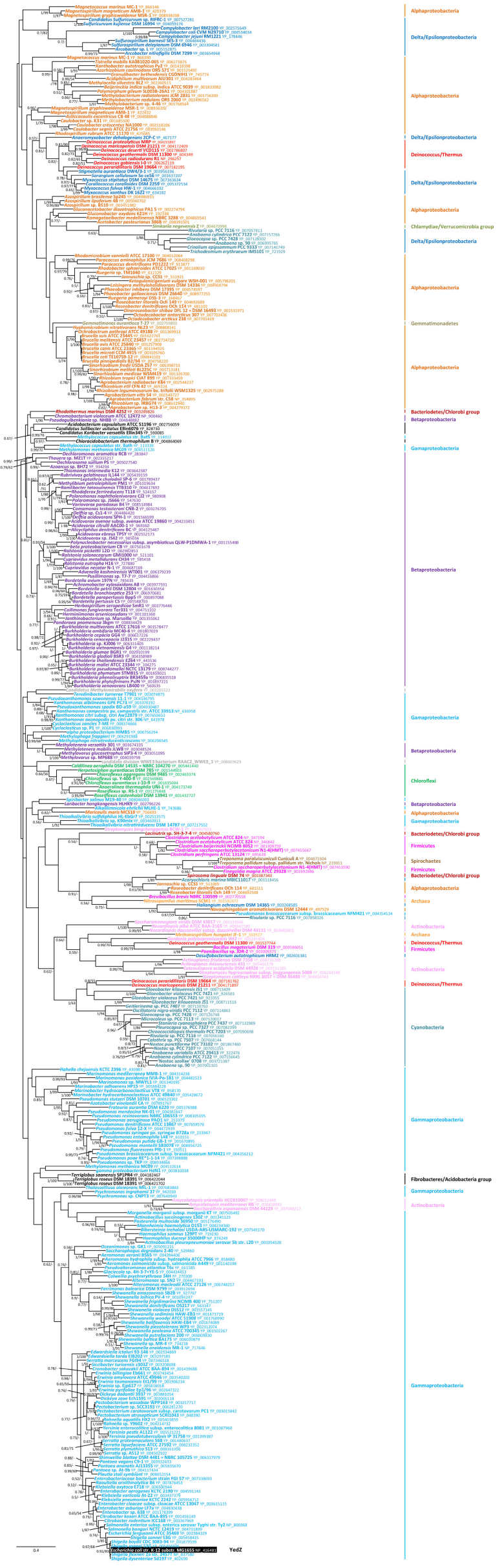




\section{RESEARCH LETTER}

Extended Data Figure 6 | Individual phylogenies of YedZ. Shown are unrooted Bayesian phylogenetic trees for YedZ (b1972, 369 sequences, 135 positions). Numbers at nodes indicate posterior probabilities computed by $\mathrm{MrBayes}^{49}$ and bootstrap values computed by $\mathrm{PhyML}^{48}$.
Only posterior probabilities and bootstrap values above 0.5 and $50 \%$, respectively, are shown. Scale bars, average number of substitutions per site. In the phylogenetic tree, YedZ from E. coli is highlighted in grey. 
Extended Data Table 1 | The MsrPQ system uses electrons from the respiratory chain to reduce free Met-0

\begin{tabular}{|c|c|c|}
\hline Strain description & Met & Met-O \\
\hline Met- & + & + \\
\hline Met- Msr- (JB590) & + & - \\
\hline Met' Msr- SupMet-O+ $($ BE100) & + & + \\
\hline Met Msr- Sup ${ }^{\text {Met-O+ }} \Delta y e d Z$ (BE105) & + & - \\
\hline Met Msr empty vector (AG272) & + & - \\
\hline Met Msr pyedY (AG273) & + & - \\
\hline Met-Msr pyedZ (AG279) & + & - \\
\hline Met-Msr- pyedYyedZ (AG274) & + & + \\
\hline Met' Msr SupMet-O+ $\Delta m e n A \Delta u b i E(B E 106)$ & + & - \\
\hline
\end{tabular}

This table shows the ability of the various strains to grow $(+)$ or not $(-)$ using Met- $\mathrm{O}$ as the sole Met source. Strains were grown for $40-72 \mathrm{~h}$ at $37^{\circ} \mathrm{C}$. The results are representative of experiments made in biological triplicate. 


\section{RESEARCH LETTER}

\section{Extended Data Table 2 | List of proteins identified as potential MsrP substrates}

\begin{tabular}{|c|c|c|}
\hline Protein & Function & $\begin{array}{l}\text { Number and percentage of } \\
\text { methionines in the protein }\end{array}$ \\
\hline SurA & Primary periplasmic chaperone & $14(3.4 \%)$ \\
\hline LolA & Outer-membrane lipoprotein carrier protein & $2(1.1 \%)$ \\
\hline Pal & Peptidoglycan-associated lipoprotein & $6(3.9 \%)$ \\
\hline MlaC & Probable phospholipid-binding protein & $4(2.1 \%)$ \\
\hline PpiA & Peptidyl-prolyl cis-trans isomerase A & $4(2.4 \%)$ \\
\hline DsbA & Thiol:disulfide interchange protein & $6(3.2 \%)$ \\
\hline CysP & Thiosulfate-binding protein & $4(1.3 \%)$ \\
\hline PotD & Spermidine/putrescine-binding periplasmic protein & $9(2.8 \%)$ \\
\hline MppA & Periplasmic murein peptide-binding protein & $7(1.4 \%)$ \\
\hline ProX & Glycine betaine-binding periplasmic protein & $6(1.9 \%)$ \\
\hline MalE & Maltose-binding periplasmic protein & $6(1.6 \%)$ \\
\hline MglB & D-galactose-binding periplasmic protein & $6(1.9 \%)$ \\
\hline $\mathrm{RbsB}$ & D-ribose-binding periplasmic protein & $4(1.5 \%)$ \\
\hline FecB & $\mathrm{Fe}^{3+}$ dicitrate-binding periplasmic protein & $7(2.5 \%)$ \\
\hline RenB & Nickel/cobalt homeostasis protein & $2(2.3 \%)$ \\
\hline ZnuA & High-affinity zinc uptake system protein & $6(2.1 \%)$ \\
\hline Ecotin & General inhibitor of pancreatic serine proteases & $4(2.8 \%)$ \\
\hline Ivy & Inhibitor of vertebrate lysozyme & $5(3.9 \%)$ \\
\hline PspE & Thiosulfate sulfurtransferase & $2(2.4 \%)$ \\
\hline YmgD & Uncharacterized protein & $4(4.4 \%)$ \\
\hline
\end{tabular}

${ }^{*}$ Referring to the mature protein without its signal sequence

Semi-quantitative two-dimensional LC-MS/MS analysis was used to identify proteins that have one or more oxidized Met residues that MsrP could reduce. The first column indicates the name of the protein, the second describes its function and the third gives the number and percentage of methionine residues in the mature protein (excluding the signal sequence), 